\title{
Cytochrome P450 CYPIAI: wider roles in cancer progression and prevention
}

\author{
Vasilis P Androutsopoulos*1,2, Aristidis M Tsatsakis ${ }^{1}$ and \\ Demetrios A Spandidos ${ }^{2}$
}

Address: ${ }^{1}$ Department of Medicine, Division of Forensic Sciences and Toxicology, University of Crete, Crete, Greece and ${ }^{2}$ Department of Medicine, Division of Clinical Virology, University of Crete, Crete, Greece

Email: Vasilis P Androutsopoulos* - vasilis_androutsopoulos@yahoo.com; Aristidis M Tsatsakis - aris@med.uoc.gr;

Demetrios A Spandidos - contact@spandidos-publications.com

* Corresponding author

Published: 16 June 2009

BMC Cancer 2009, 9:187 doi:10.1 186/147|-2407-9-187
Received: 23 January 2009

Accepted: 16 June 2009

This article is available from: http://www.biomedcentral.com/I47/-2407/9//87

(c) 2009 Androutsopoulos et al; licensee BioMed Central Ltd.

This is an Open Access article distributed under the terms of the Creative Commons Attribution License (http://creativecommons.org/licenses/by/2.0), which permits unrestricted use, distribution, and reproduction in any medium, provided the original work is properly cited.

\begin{abstract}
CYPIAI is one of the main cytochrome P450 enzymes, examined extensively for its capacity to activate compounds with carcinogenic properties. Continuous exposure to inhalation chemicals and environmental carcinogens is thought to increase the level of CYPIAI expression in extrahepatic tissues, through the aryl hydrocarbon receptor (AhR). Although the latter has long been recognized as a ligand-induced transcription factor, which is responsible for the xenobiotic activating pathway of several phase I and phase II metabolizing enzymes, recent evidence suggests that the AhR is involved in various cell signaling pathways critical to cell cycle regulation and normal homeostasis. Disregulation of these pathways is implicated in tumor progression. In addition, it is becoming increasingly evident that CYPIAI plays an important role in the detoxication of environmental carcinogens, as well as in the metabolic activation of dietary compounds with cancer preventative activity. Ultimately the contribution of CYPIAI to cancer progression or prevention may depend on the balance of procarcinogen activation/detoxication and dietary natural product extrahepatic metabolism.
\end{abstract}

\section{Background}

Cytochrome P450s are haem-containing enzymes, which catalyze various Phase I metabolism reactions, such as C, N- and S- oxidation and dealkylation. Cytochrome P450 CYP1A1 is one of the three members of the CYP1 family, which is found mainly in extrahepatic tissues and participates in the metabolism of a vast number of xenobiotics, as well as a small number of endogenous substrates. Among the different reactions catalyzed by CYP1A1, hydroxylation at a vacant position of an aromatic ring is considered to be the hallmark for the initiation of carcinogenesis, through the formation of highly reactive conver- sion products that can cause oncogenic mutations in experimental animals and humans [1,2]. The transcriptional activation of the CYP1A1 gene is mediated by the binding of environmental pollutants and inhalation chemicals, notably substrates of the CYP1A1 enzyme, to the cytosolic receptor AhR and is also mediated by its translocation to the nucleus and subsequent formation of a dimer, which interacts with the corresponding xenobiotic response elements to activate transcription [3]. Although the xenobiotic-activating pathway of AhR has been well established for a large number of exogenous ligands, the receptor has been shown to participate in impor- 
tant developmental and cell-regulatory processes, except foreign compound metabolism. These functions coexist with the well-characterized toxicological roles of the receptor. As a result the exact function of CYP1A1 appears to be a lot more complex than initially thought. Recent in vivo investigations suggest that CYP1A1 may function as a carcinogen-detoxication enzyme, whereas the paradoxical activation of natural dietary compounds with chemopreventative activity provides further insight into the cancerprotecting role of this enzyme.

In this review, a comprehensive summary of the carcinogen-activating role of CYP1A1 is presented, in terms of substrate specificity, mechanisms of carcinogen activation, polymorphisms and extrahepatic expression. In addition, experimental evidence of the interaction of AhR with various biological pathways, including cell cycle control, apoptosis, mitogen-activated protein kinases, estrogen receptor, glucocorticoid receptor and hypoxia signaling are addressed. Finally, recent findings with transgenic animals and in vitro pharmacological evidence, which point towards a cancer-protecting role of this enzyme, are presented.

\section{Discussion \\ Mechanism of activation of procarcinogens by CYPIAI}

The deleterious effects of most of the chemical carcinogens encountered in the environment are attributed to metabolic activation by cytochrome P450s to highly reactive conversion products. It has been proven that such reactive metabolites cause carcinogenicity in experimental animals and humans whereas their corresponding parent compounds are chemically inactive [4,5]. Cytochrome P450 CYP1A1 is one of the more significant P450 enzymes involved in this process. CYP1A1 metabolizes carcinogens to epoxide intermediates, which are further activated to diol epoxides by the enzyme epoxide hydrolase. The widely accepted paradigm used to demonstrate this process is the activation of the carcinogen Benzo[a]pyrene $\mathrm{B}[a] \mathrm{P}$.

The metabolic fate of the prototype carcinogen $\mathrm{B}[a] \mathrm{P}$ was extensively studied in the mid-1970s in humans [4]. It was initially thought that the metabolite $\mathrm{B}[a] \mathrm{P}-4,5$-epoxide, the so-called K-region epoxide, was the ultimate carcinogen. However subsequent investigations clearly demonstrated that $\mathrm{B}[a] \mathrm{P}-7,8$-diol-9,10-epoxides, referred to as bay region epoxides, were highly reactive towards DNA and thus were classified as the ultimate carcinogenic metabolites of $\mathrm{B}[a] \mathrm{P}$. The exact mechanism of metabolic activation involves the oxidation of $\mathrm{B}[a] \mathrm{P}$ to $\mathrm{B}[a] \mathrm{P}-7,8-$ oxide, and subsequent hydrolysis to $\mathrm{B}[a] \mathrm{P}-7,8-d i o l$ and the two enantiomers (+)-B $[a] \mathrm{P}-7,8$-diol and (-)-B $[a] \mathrm{P}-7,8-$ diol [6]. A final oxidation of each of these metabolites produces four diol epoxides, which are highly mutagenic in Ames Salmonella tester strains and Chinese Hamster V79 cells. Additionally the epoxides are denoted as bay region epoxides due to their ability to cause oncogenic mutations in specific parts of the DNA $[2,6,7]$. The metabolite (+)-B[a]P-7,8-diol-9,10-epoxide-2 was identified as the most reactive of the four metabolites in producing tumors in newborn mice. This metabolite was considered to be the ultimate carcinogenic conversion product of $\mathrm{B}[a] \mathrm{P}$, because its level of carcinogenicity paralleled that of $\mathrm{B}[a] \mathrm{P}$ and (-)-B $[a] \mathrm{P}-7,8$-diol. The structures of $\mathrm{B}[a] \mathrm{P}$ and its metabolites are shown in Figure 1A.

With the exception of the hydrolysis step catalyzed by epoxide hydrolase, the oxidation reactions of $\mathrm{B}[a] \mathrm{P}$ activation are promoted by cytochrome P450s. Among the different families, CYP1A1 and CYP1B1 exhibit the highest catalytic specificity towards $\mathrm{B}[a] \mathrm{P}$, as shown by in vitro experiments with recombinant human $\mathrm{P} 450$ enzymes from E. Coli and Trichoplusia ni cells [6]. Other PAHs have been investigated for their carcinogenic action and found to follow the same metabolic activation pattern as $\mathrm{B}[a] \mathrm{P}$. The carcinogen 7,12-Dimethyl benzanthracene $(7,12$ DMBA) is oxidized to 7,12-DMBA-3,4-oxide by CYPs, further hydrolyzed to its corresponding diol and finally oxidized by CYPs to 7,12-DMBA-3,4-oxide-diol-1,2-epoxide, which is the ultimate carcinogen (Figure 1B) [6]. Carcinogenic compounds which fall in the PAH category and are considered to follow the bay region activation theory include benz $[a]$ anthracene, benzo $[b]$ fluoranthrene, benzo[c]phenanthrene, chrysene, benzo[g]chrysene and 5,6-dimethylchrysene. The above-mentioned PAHs showed selective in vitro metabolism towards human recombinant CYP1A1 and CYP1B1 and were capable of inducing DNA-modifying products in the Salmonella typhimurium NM2009 tester strain [8]. CYP1A1 is further involved in the activation of aflatoxin $\mathrm{B} 1$, a carcinogenic mycotoxin present in foodstuffs, to its corresponding 8,9epoxide in rabbit lung and liver. Further in vivo investigations have shown that CYP1A1 is involved in $\mathrm{B}[a] \mathrm{P}$ induced carcinogenesis in mice which were positive for the aryl hydrocarbon receptor AhR $(+/+)[6,9,10]$. Studies in this transgenic strain demonstrated an increase in CYP1A1 expression in both liver and lung, following treatment of PAHs, such as 5-methylchrysene and 7,12DMBA. Hence, the carcinogenic potential of CYP1A1 in the activation of PAHs has been well documented both in vitro and in vivo.

CYP1A1 was thought to be uniquely responsible for $\mathrm{PAH}$ activation, until the early 1990s, when CYP1B1 was identified. Generally the substrate specificities of the two enzymes towards various pro-carcinogens and pro-mutagens are found to be very similar, even though recom- 
A<smiles>c1ccc2c(c1)cc1ccc3cccc4ccc2c1c34</smiles><smiles>[Mg][Mg]</smiles>

$\mathrm{B}[a] \mathrm{P}$

Epoxide hydrolase

$\mathrm{B}[a] \mathrm{P}-7,8$-oxide

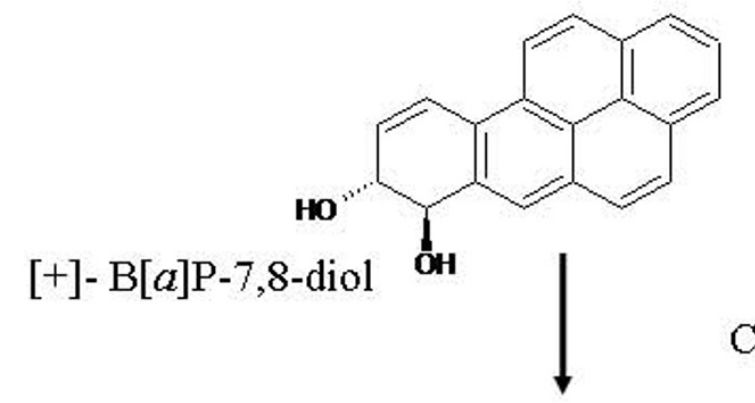

CYP1A1

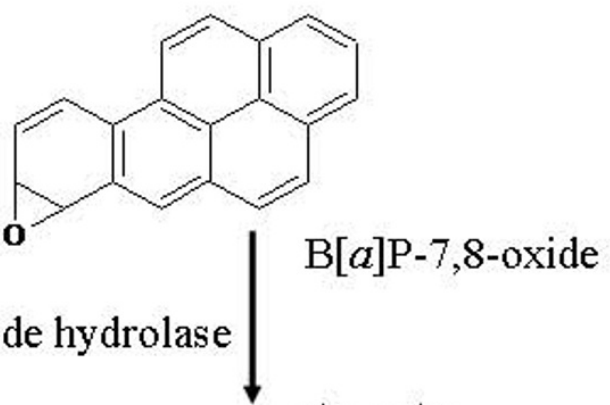<smiles></smiles><smiles></smiles>

$[+]$ - $\mathrm{B}[a] \mathrm{P}-7,8$-diol-9,10-epoxide $\quad[-]-\mathrm{B}[a] \mathrm{P}-7,8$-diol-9,10-epoxide

B

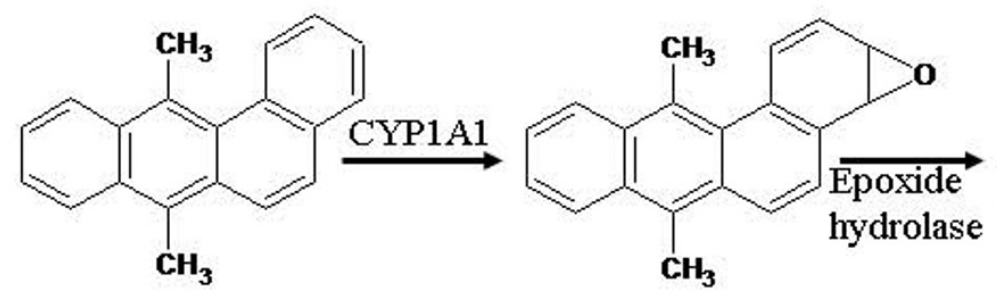

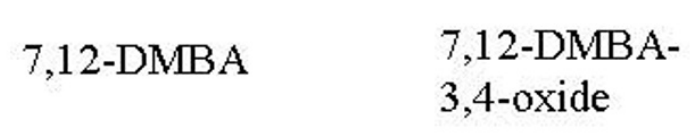

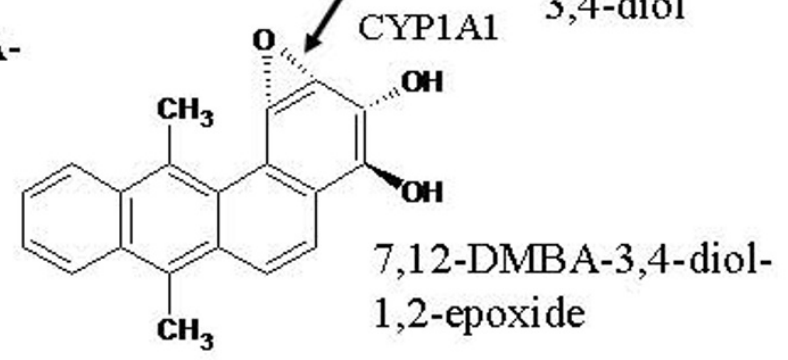

Figure I

Metabolic activation of (A) B [a]P and (B) 7, I 2-DMBA to the carcinogenic metabolites B [a]P-7,8-diol, B [a]P7,8-diol-9, I0-epoxide and 7,I 2-DMBA-3,4-diol, 7, I 2-DMBA-3,4-diol-I,2-epoxide, respectively, by CYPIAI and epoxide hydrolase [6]. 
binant human CYP1A1 and CYP1B1 differ in their region and stereochemical selectivity for the activation of certain compounds e.g. DB[a, l]P $[6,11,12]$.

The metabolic activation of heterocyclic amines is also catalyzed by CYP1A1. PhIP or 2-Amino-1-methyl-6-phenylimidazo[4,5-b]pyridine is the most abundant heterocyclic amine in food, which is a product of cooked meat and fish. The hydroxylation of PhIP at position $\mathrm{N}^{2}$ - is considered as the initiation step of PhIP-induced carcinogenesis [13]. Hydroxylation at position $N^{2}$, catalyzed by CYPs, is followed by esterification with $\mathrm{N}$-acetyltransferase or sulfotransferase to produce the corresponding esters $N^{2}$-acetoxy-PhIP and $N^{2}$-sulfonyloxy-PhIP [14]. These esters form covalent bonds with DNA to yield $N^{2}$ (2-deoxyguanosin-8-)-PhIP, and with proteins to the metabolite 5-hydroxy-PhIP, a degradation product occurring spontaneously. The chemical structures of PhIP and metabolites are shown in Figure 2.

PhIP-DNA adducts have been detected in various tissues of rats and mice, as well as in the colon of humans [15]. Although CYP1A2 is a significant isoform involved in PhIP activation in the liver, CYP1A1 plays an equally important role in this process in extrahepatic tissues, such as the lung. Early studies with knockout mice have shown that PhIP-DNA adducts were detected in extrahepatic tissues of Cyp1a2 null mice, implying a role of CYP1A1 in PhIP metabolic activation [16]. A recent study by Gonzalez demonstrated that the $N^{2}$-hydroxylation of PhIP was increased almost 2-fold in lung homogenates of Cyp1a2 null mice, compared to wild-type mice whereas it reached minimal levels in Cyp1a1 null mice [13]. In addition, PhIP-DNA adducts were significantly higher in lung samples from Cyp1a2 null strains, as opposed to Cyp1a1 null mice and almost equivalent with the amount present in wild-type mice [13]. In the humanized CYP1A2 (CYP1A2_CYP1A1 Cyp1a2 null) transgenic strain it was shown that $\mathrm{N}^{2}$-hydroxylation was favored over 4 '-hydroxylation of PhIP [14]. This implies that in humans oxidation of the exocyclic amino group ( $N^{2}$-hydroxylation) is the major route of metabolism, followed by glucuronidation, whereas in rats and rodents 4 ' hydroxylation to 4'hydroxy PhIP followed by phase II conjugation is the predominant metabolic pathway, which has been shown to be associated with detoxication rather than metabolic activation. However, the humanized CYP1A1 (CYP1A2_CYP1A1 Cyp1a1 null) strain was not examined in this study, in terms of PhIP metabolism [14].

CYP1A1 has also been shown to be involved in the activation of tobacco-related N-nitrosamines, such as NNK, along with CYP1A2 and CYP2A6 [17]. Such compounds induce cancer in experimental animals and their activation step requires hydroxylation of the $\alpha$-position carbon atom of N-nitroso group, a reaction catalyzed by CYPs [18].

\section{CYPIAI induction is mediated by the AhR, a receptor involved in various biological processes}

The induction of CYP1A1 expression is mediated through a specific cytosolic receptor, the Aryl hydrocarbon receptor or AhR. AhR exists as part of a cytosolic protein complex, which consists of two Hsp-90 heat-shock proteins, a Hsp-90-interacting co-chaperone p23 and an immunophillin-like protein XAP2 or AIP [19]. In the presence of an exogenous ligand such as $\mathrm{B}[a] \mathrm{P}$ or the industrial byproduct 2,3,7,8-tetrachlorodibenzo-p-dioxin (TCDD) the receptor complex translocates to the nucleus, where it heterodimerizes with another protein, the aryl hydrocarbon nuclear translocator or ARNT (Figure 3). This heterodimer binds to consensus regulatory sequences termed AhREs (Aryl hydrocarbon response elements) XREs (Xenobiotic response elements) or DREs (Dioxin response elements), located in the promoter region of AhR target genes such as CYP1A1 and CYP1A2 and initiates their transcription by recruiting RNA polymerase II (Figure 3) [19]. The transcription of CYP1A1 is inhibited by the AhR-related factor Aryl hydrocarbon receptor repressor or AhRR, which localizes in the nucleus in the form of a dimeric protein along with ARNT (Figure 3). The AhRR/ARNT heterodimer acts as a repressor both by stopping transcription initiated at the XREs and by competing with AhR for heterodimer formation with ARNT. All AhR, ARNT and AhRR are members of the bHLH (basic helixloop-helix) PAS (Per-ARNT-Sim) family of proteins. The bHLH motif is shared by other transcription factors such as Myc and MyoD and is the protein part essential for DNA binding of the AhR complex [20]. Heterodimerisation of AhR/ARNT is facilitated by interactions between bHLP and PAS domains. Further interactions of the AhR/ ARNT heterodimer with transcription factors such as Sp1 and NF-1 are essential to enhance the expression of the CYP1A1 gene. Other proteins which possess HAT (Histone Acetyltrasnferase) activity and act as co-activators include SRC-1 (Steroid receptor co-activator), NcoA2 (Nuclear co-activator 2), p/CIP and p300. SRC-1, NcoA2 and $\mathrm{p} / \mathrm{CIP}$ have been shown to associate with the mouse Cyp1a1 enhancer region and to enhance XRE-driven reporter gene transcription [20-22]. Using ChIP analysis, Hatkinson has shown that co-activators such as p300 and $\mathrm{p} / \mathrm{CIP}$ bind to the enhancer but not to the promoter region of the mouse Cyp1a1 gene, following TCDD treatment, whereas RNA polymerase II binds only to the promoter and not to the enhancer region of the same gene [23]. In contrast, Puga and co-workers found that p300 binds both to the enhancer and promoter following $\mathrm{B}[a] \mathrm{P}$ treatment [24]. It is believed that co-activator recruitment, enhances the gene transcription of CYP1A1 and aids in the binding of Pol II and transcription factors to the CYP1A1 
<smiles>Cn1c(N)nc2ncc(-c3ccccc3)cc21</smiles>

\section{PhIP}

CYP1A1/CYP1A2

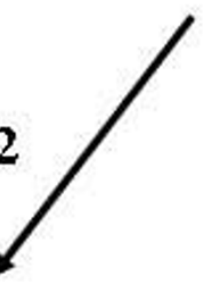

HO<smiles>Cn1c(N)nc2ncc(-c3ccc(I)cc3)cc21</smiles>

$4^{\circ} \mathrm{OH}$ metabolite

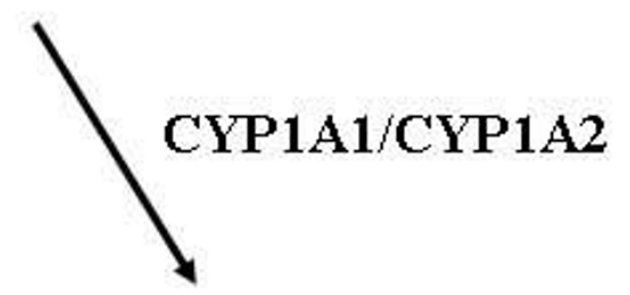<smiles>Cn1c(NO)nc2ncc(-c3ccccc3)cc21</smiles>

Acetoxy, sulfonyloxy esters

$N^{2}$ hydroxylated metabolite

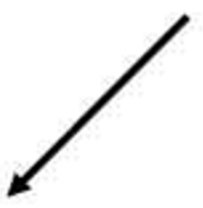

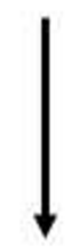

\section{DNA adducts}

\section{Figure 2}

Metabolic activation of PhIP to the carcinogenic metabolite N2-hydroxy PhIP by CYPIA enzymes and epoxide hydrolase [14]. 


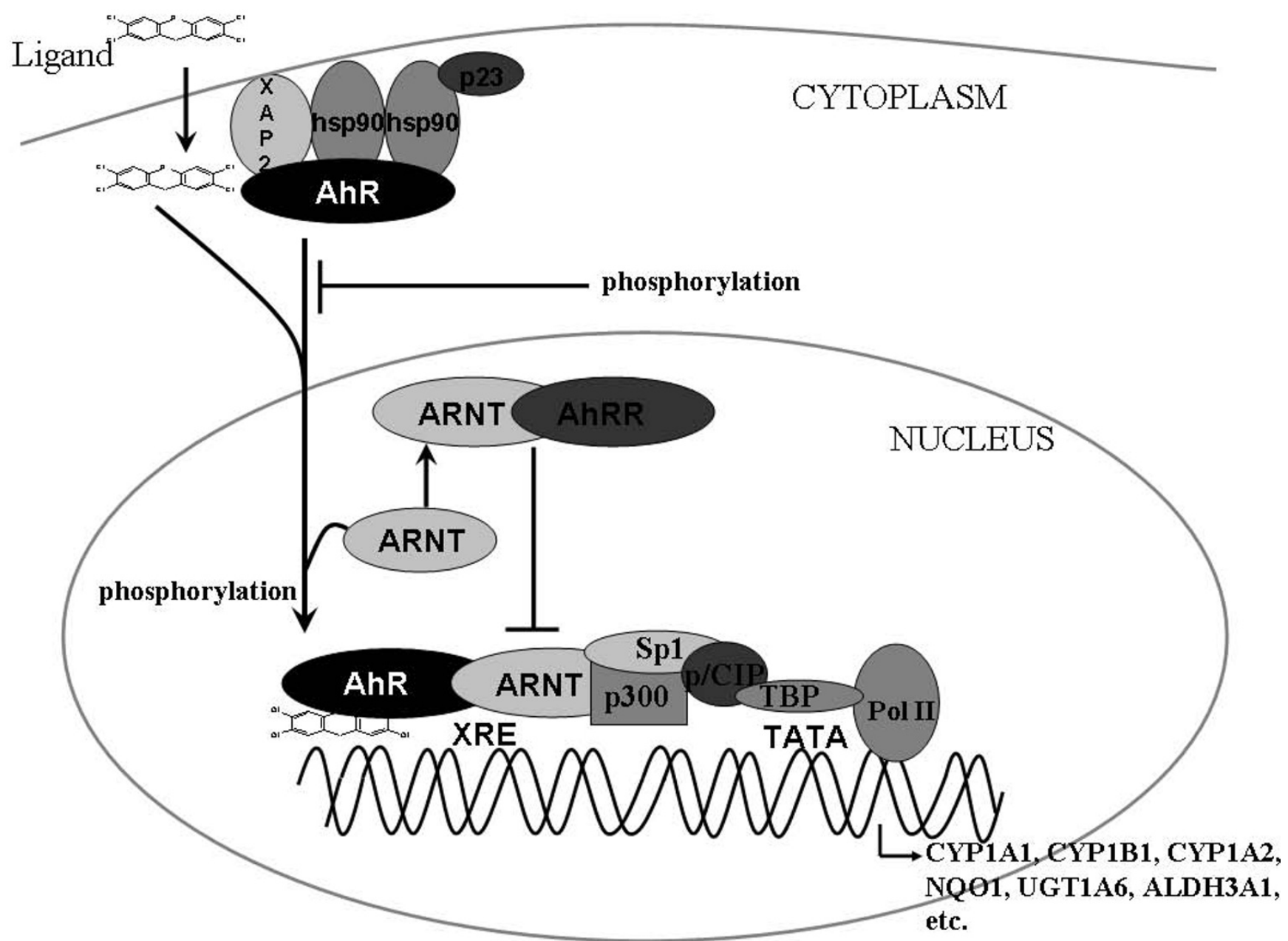

Figure 3

AhR ligand-mediated activation of phase I and II metabolizing enzyme genes. The diagram represents a basic model of the molecular events following the entry of an AhR ligand, such as TCDD, in the cell. Upon ligand binding the AhR complex dissociates with XAP2, p23 and HSP90 proteins and translocates to the nucleus. Nuclear import is inhibited by phosphorylation reactions of either Ser-1 2 or Ser-36 residues of the Nuclear localization signal (NLS), while phosphorylation of phosphotyrosine residues in the carboxy terminal of the AhR is required for the formation of a functional AhR/ARNT complex [19]. Binding of the AhR/ARNT complex to XRE is inhibited by the ARNT/AhRR dimer. Initiation of the transcription of genes encoding for phase I and phase II metabolizing enzymes occurs via the interaction of several transcription factors such as Sp I and co-activators such as p-300 and p/CIP, which eventually leads to binding with TBP (TATA binding protein) and subsequent recruitment of RNA polymerase II [20-22]. There is a great number of other transcription factors, co-activators and general transcription factors (GTFs) involved in this process, which are not shown for clarity.

promoter, thus facilitating gene transcription. Nevertheless, it still remains unclear whether participation of coactivator proteins is the same in all tissues, where CYP1A1 is inducible. Further investigation is required for a conclusive report on the molecular events involving co-activator, transcription factor and Pol II recruitment in the transactivation of the CYP1A1 gene.

This proposed mechanism of CYP1A1 induction also applies to certain Phase II xenobiotic metabolizing enzymes, such as NQO1, UGT1A6, ALDH3A1 and several glutathione S-transferases, and was initially thought to be the primary role of AhR in the mid 1990s [3]. However, recent discoveries have illuminated a wider function of AhR, than initially thought. It is now generally accepted that the receptor is involved in physiological functions beyond xenobiotic metabolism, such as regulation of cell growth, apoptosis, hypoxia signaling, cell adhesion and matrix metabolism $[19,25,26]$. Based on accumulating experimental data we broadly categorized the AhR in 
three important pathways. The first is the extrinsic AhR xenobiotic signaling pathway, which usually requires an exogenous ligand for activation and results in the induction of several Phase I and Phase II metabolizing genes. A second network of pathways involves the interaction of the AhR with various cell-signaling proteins, such as $\mathrm{Rb}$ and $\mathrm{E} 2 \mathrm{~F}$ in the presence or absence of an inducer. The third pathway is the intrinsic AhR pathway, which remains elusive, in terms of exact mechanism of action and is thought to be dependent on an endogenous ligand and play key roles in important physiological and developmental processes. The above mentioned pathways are likely to interact with one another, proving that the exact function of the receptor is a lot more complex, than initially thought.

\section{Interaction of $A h R$ with protein kinase $C$ and tyrosine kinases}

The first line of evidence, which supports a positive interaction between AhR and PKC is derived from early studies in mice, where it was shown that the inhibition of PKC blocks ligand-activated DNA binding of AhR/ARNT heterodimers, leading to a decreased Cyp1 gene expression $[27,28]$. Previous studies have provided further insight to a more complex signaling mechanism by which the activity of the AhR complex is regulated by PKC. AhR contains a nuclear localization signal (NLS), composed of the amino acid residues 13-16 and 37-39, and a nuclear export signal (NES) [29]. Ikuta showed in 2004 that the ligand-dependent nuclear input of AhR is inhibited by phosphorylation of either Ser12 or Ser36 by PKC. The replacement of Serine residues with Alanine does not affect nuclear translocation, whereas replacement with Asp retains the mutant AhR in the cytoplasm. PKC, however, does not appear to be directly involved in AhR-mediated transcription, as Ala and Asp replacement mutants in in vitro luciferase reporter assays had much lower transcriptional activity than the wild type. By analogy to the regulation of NLS, phosphorylation of the Ser 68 residue by $\mathrm{p} 38$ of NES, has been demonstrated to activate the export of the receptor from the nucleus [30]. In addition, phosphorylation at the tyrosine residues of the carboxy terminal half of $A h R$ is required for the formation of the functional AhR/ARNT heterodimer, whereas phosphorylation of the Serine residues of HSP90 proteins modulates the formation of a functional cytosolic AhR complex [19]. Thus, it appears that the induction of CYP1A1 is tightly regulated by phosphorylation reactions occurring at the AhR functional domains.

\section{Cross-talk of MAPK kinases with AhR}

MAPK kinases are serine threonine kinases, involved in inflammatory responses, apoptosis, cell growth and further mitogenic and developmental events. It is becoming increasingly accepted that the AhR pathway is linked to an extent with MAPKs. Prototype AhR activators have been shown to have a positive effect on the activation of several MAPKs. For example, the TCDD-induced modulation of epithelial morphology causes the activation of JNK [31]. These dioxin-mediated effects can be mimicked by a constitutive expression of AhR. In addition, ablation of JNK2 and ERK affects TCDD-induced CYP1A1 transactivation by decreasing its expression in mouse thymus and testis [32]. It has been further noted that CYP1A1 and CYP1B1 mRNA and protein expression can be induced in human keratinocytes, after UV exposure. It has been proposed that thryptophan-derived photoreactive products, which are weak agonists of AhR are responsible for this effect, even though the contribution of JNK and p38 activation, which occurs under UV radiation, cannot be entirely dismissed. The induction of ERK and JNK was also noted in A-549 human lung carcinoma and Hepa-1 mouse hepatoma cells, which possess a functional AhR battery, following treatment of TCDD or $\mathrm{B}[a] \mathrm{P}[33,34]$. In addition, the interaction of AhR with ERK, appears to be critically linked to the function of the receptor, as ERK inhibitors were shown to prolong TCDD-induced AhR degradation. More importantly it has been shown in Hepa1c1c7 cells that ERK is physically associated with AhR, and that the overexpression of ERK1 promoted AhR degradation, suggesting that ERK plays an important role in the proteolysis of the receptor [35]. Moreover, constitutively active MEK1, which is the MAPKK upstream of ERK $1 / 2$, increased the TCDD-mediated induction of CYP1A1 via the AhR [33]. Based on previous investigations regarding cross-talk of the MAPKs with AhR, it can be concluded that exogenous ligands of the receptor contribute to the upregulation of several MAPKs, which in turn exert a positive interaction on the translocation of the AhR complex to the nucleus and subsequently the activation of several Phase I and Phase II metabolizing genes, including CYP1A1.

\section{Role of AhR in cell cycle progression}

The effects of AhR in cell cycle progression are distinct, depending on the presence or absence of an exogenous ligand. Although in the absence of a ligand AhR promotes progression of the cell cycle as shown in mouse hepatoma Hepa1c1c7, AhR null MEF cells and HepG2 human hepatoma cells transfected with AhR siRNA, accumulating data strongly suggests that TCDD inhibits cell proliferation [36-40]. TCDD induces cell cycle arrest in normal cells and inhibits the growth of MCF-7 breast adenocarcinoma cells, stimulated by $17-\beta$ oestradiol, as well as proliferation of the fish hepatocellular carcinoma PLHC-1 cell line and the androgen-induced LNCap human prostate cancer cell line [41-43]. A delayed $\mathrm{G}_{1}$ to $S$ phase transition has been noted in 5L hepatoma cell cultures, following TCDD treatment, which was attributed to induction of the p27Kip1 cell cycle inhibitor. CYP1A1 
enzyme activity is thought to act as a negative regulator to the length of AhR activation as 5L cells that were treated simultaneously with serum and the CYP1A1 suicide substrate 1-PP showed prolonged AhR activation and p27Kip1 induction, similar to that of TCDD alone [44,45]. Additional data have shown that AhR blocks the phosphorylation of $\mathrm{RB}$ in $\mathrm{G}_{1}$ by forming complexes with its hypophosphorylated form [46]. This interaction is supported by two AhR domains, one found in the cyclin D LXCXE motif and the other present within the transactivation domain of the receptor [47]. The end result is the repression of E2F-dependent gene expression, which involves proteins such as cyclin E, CDK2, DNA polymerase $\alpha$ and DHFR and the repression of RB-target genes, as well as the exclusion of co-activator proteins from RB-promoters, suggesting an RB-corepressor function of the AhR [48]. In contrast to these findings, investigations in stably integrated AhR variants in fibroblasts from AhR null mice, show that $\mathrm{AhR}^{+/+}$proliferate faster than $\mathrm{AhR}^{-/-}$fibroblasts, while the addition of TCDD did not change the rate of proliferation [49]. This indicates a ligand-independent AhR regulation of the cell cycle. In AhR $\%$ cells cyclin-CDK complexes were downregulated whereas the expression of cell cycle inhibitors was upregulated [49]. In addition, a recent study has shown that constitutively active AhR contributes to basal CYP1B1 but not CYP1A1 mRNA levels in immortalized and malignant mammary cell lines, whereas AhR hyperactivation by TCDD activates both genes, which implies a contribution of AhR and CYP1B1 prior to tumor formation [50]. These two contradictory bodies of evidence imply the wider function of AhR in the presence and absence of a ligand. It is also important to note that the precise function of AhR in cell proliferation may be different among the various cell or tissue types [19].

\section{Interaction of AhR with other pathways}

AhR has been shown to interact with the glucocorticoid receptor (GR) both in vitro and in vivo [51-54]. The glucocorticoid dexamethasone has been shown to enhance TCDD-induced expression of CYP1A1, in a rat hepatoma and fish hepatocellular carcinoma cell lines [54,55]. Although many studies have been conducted in rodent models in terms of AhR and GR cross-talk, little information is available for humans [51-53]. Recent evidence from studies in HepG2 cells and primary cultures of human hepatocytes has shown that dexamethasone reduces both basal and inducible CYP1A1 EROD activity $[56,57]$. Furthermore, dexamethasone was shown to have direct effects on the modulation of TCDD-induced transcriptional activation as well as the degradation of AhR in HepG2 cells. In contrast, experiments conducted in human hepatocytes experiments with the glucocorticoid receptor antagonist RU486 in the presence and absence of dexamethasone, showed a downregulation of basal and
TCDD-induced AhR and GR mRNAs and AhR protein $[56,57]$. These findings show that dexamethasone controls CYP1A1 expression in human hepatocytes and HepG2 cells through interactive regulatory cross-talk between GR and AhR receptors.

Cross-talk of AhR and ARNT with the oestrogen receptor $\alpha(\mathrm{ER} \alpha)$ has also been established in a number of different systems $[58,59]$. TCDD does not bind to ER $\alpha$, but it inhibits $\mathrm{ER} \alpha$ signaling. More importantly ER $\alpha$ plays a significant role in modulating AhR activity, as it has been reported by in vitro and in vivo studies that treatment of TCDD and E2 results in an increased induction of CYP1A1, compared to TCDD treatment alone $[60,61]$. $\mathrm{ER} \alpha$ has a direct interaction with the CYP1A1 promoter, suggesting that it acts as a co-regulator of AhR-mediated transcriptional activation [60]. In human bronchial epithelial cells ER $\alpha$ increased the basal mRNA levels of CYP1B1 and the inducible protein levels of CYP1A1, thus regulating the expression of these genes at a transcriptional and a translational level, respectively [62]. The interaction of ER $\beta$ with AhR and ARNT has also been suggested [63]. Such literature implies that both ER $\alpha$ and ER $\beta$ can regulate the expression of carcinogen-metabolizing genes such as CYP1A1.

The dimerisation partner of AhR, ARNT is also called HIF$1 \beta$ (Hypoxia inducible factor $1 \beta$ ). In addition to binding with AhR, ARNT dimerises with the protein HIF- $1 \alpha$ to form HIF-1 (Hypoxia inducible factor). HIF-1 $\alpha$ is also a member of basic helix-loop-helix (bHLH) Per-ARNT-Sim (PAS) proteins $[64,65]$. Upon the formation of HIF-1, the induction of transcription of hypoxia-related genes such as VEGF and PDGF is initiated, by the binding of HIF- $1 \alpha$ to hypoxia response element (HREs) sequences [66]. Since the sequestration of ARNT is challenged by both AhR and HIF- $1 \alpha$, certain studies have supported the notion that the limiting cellular factor ARNT is shared between two pathways [67-69]. In this sense, reciprocal crosstalk between hypoxia and dioxin signal transduction pathways has been demonstrated to occur in vitro and in vivo [67]. Hypoxia may downregulate the expression of $\mathrm{AhR}$, and subsequently CYP1A1, as dioxin upregulates the expression of erythropoietin via AhR-ARNT binding to DREs upstream of the transcriptional start site [67]. Increased oxygen supplementation, or hyperoxia has been shown to significantly induce CYP1A1 mRNA, protein and activity in human lung cell lines by means of an AhRdependent mechanism [70].

\section{CYPIAI expression}

CYP1A1 is believed to be the primary extrahepatic enzyme involved in the metabolism of carcinogens. Consequently, numerous studies have investigated the expression patterns of CYP1A1 in extrahepatic tissues, which are 
largely exposed to environmental carcinogens, such as the lung. CYP1A1 has been detected in lung microsomes from human subjects by Western immunoblotting, although the expression was rather weak [71], while EROD activity assays demonstrated active CYP1A1 (range 7-31 nmol/ $\mathrm{mg} /$ protein/min). This finding has been supported by similar results from different research groups. CYP1A1 mRNA was detected in lung specimens from 27 subjects by semi-quantitative RTPCR in the presence and absence of prototypical and atypical inducers, such as TCDD and pyridine, nicotine and omeprazole respectively [72]. A previous study from the same research group reported on the expression of CYP1A1 to mRNA, the protein and activity levels for some lung specimens, even though considerable variability was noticed in the levels of proteins and transcripts [73]. CYP1A1 expression has further been reported in 40 out of 107 human lung adenocarcinomas and 21 out of 57 mixed bronchioalveolar carcinomas by immunohistochemistry, whereas the expression of both AhR and CYP1A1 was associated with smoking in lung adenocarcinoma patients [74]. Tobacco smoking was shown to be associated with CYP1A1 methylation in the lung in another study, as lung samples from active smokers which lack methylation of the CYP1A1 promoter exhibited slightly higher pulmonary EROD activity, in the regression models for age and daily consumption of tobacco [75]. In addition, the expression of CYP1A1 and AhR in small-cell lung carcinoma has been proposed as a putative diagnostic marker and has also been correlated with a history of cigarette smoking [76,77].

Based on these observations the exact function of CYP1A1 in extrahepatic tissues, such as the lung remains unknown. Most studies that have examined the CYP1A1 expression profile in lung tissues have largely been influenced by the paradoxical induction of the enzyme by environmental chemicals, as a result of continuous exposure to them. Other studies have attempted to explore a differential overexpression of CYP1A1 between tumor and normal cells, which can potentially add to the various applications of the enzyme in cancer pathology and treatment. Murray and colleagues have performed a series of studies on the expression of the extrahepatic CYPs in various tissues from normal and cancerous origin, in the absence of an inducer. The most significant finding of this research group was the identification of the enzyme CYP1B1 as a tumor marker, since the CYP1B1 protein was detected in a vast range of tumor tissues, irrespective of their oncogenic origin. Notably, however, the protein was absent in the corresponding normal samples [78]. Murray et al. have drawn similar associations regarding the differential overexpression of CYP1A1 in non-cancerous and cancerous tissues although this CYP1 isoform was shown to be present in a smaller range of tumors, compared to CYP1B1. CYP1A1 is present to a greater extent in malig- nant than in normal breast tissues, as determined by mRNA level expression [79-81], whereas in neoplastic mammary tissue oestradiol C-2 hydroxylase activity, which is a marker of CYP1A1 activity, was observed [82]. CYP1A enzymes were also present in a small percentage of non-neoplastic samples of oesophageal tissue, whereas in oesophageal carcinomas the enzymes were expressed in at least $60 \%$ of the samples [83]. Cytochromes P450 CYP1A were further detected in $68 \%$ of the urinary bladder tumors and their expression correlated with bladder tumor grade [84]. Such findings add to the well-established carcinogen-activating role of CYP1A1, since a higher expression of the enzyme would be expected in pre-malignant or malignant tissues due to the continuous exposure and subsequent metabolism by PAHs and related compounds.

Several studies have investigated the expression of CYP1A1 in human placenta cells because of the substrate specificity towards oestradiol and the potential carcinogenic and harmful effects to the developing fetus. Xenobiotic metabolism in the placenta is thought to be critical, particularly in the first trimester of pregnancy, whereas the activity of CYP-metabolizing enzymes declines in the second and third trimesters $[85,86]$. CYP1A1 has been found to be actively present in human placenta obtained from smokers, whereas in microsomes prepared from nonsmokers the activity was considerably lower [87]. In the BeWo, the human choriocarcinoma cell line, CYP1A1, was readily induced as reported by Western immunoblotting and the EROD assay in the presence of PAHs (3-methylcholanthrene, 1,2-benzanthracene, $\alpha$-napthoflavone), while in the absence of any inducer activity was minimal [88]. CYP1A1 activity in placenta tissues from subjects who were smokers has been well supported by other studies $[89,90]$. Elevated CYP1A1 activity in such tissues may contribute to several adverse birth outcomes, such as growth retardation and premature birth.

Further extrahepatic tissues in which CYP1A1 has been shown to be present include the intestine and the skin. It is becoming increasingly accepted that intestinal metabolism is a significant contributor to the hepatic metabolism of certain classes of xenobiotics [91]. CYP1A1 mRNA has been detected at low levels in the duodenum and jejunum of some donors $[87,92,93]$. Similar associations between smoking and CYP1A1 expression in the human duodenum were observed, compared to other extrahepatic tissues, i.e. CYP1A1 protein and activity were elevated in smokers [87]. CYP1A1 mRNA expression has also been detected in the skin, as well as in normal human keratinocytes. Finally recent studies have demonstrated the upregulation of CYP1A1 mRNA, protein and enzymatic activity in HUVECs, as well as human endothelial cells under shear stress, suggesting that an increased expression 
reflects an anti-atherogenic endothelial cell phenotype $[94,95]$. Constitutive CYP1A1 mRNA protein was also noted by immunostaining in endothelial cells [95].

It is generally accepted in the literature that as a result of exposure to environmental compounds with pro-mutagenic/pro-carcinogenic activity, the basal expression of CYP1A1 in extrahepatic tissues is linked to a great extent to the mechanism of chemical carcinogenesis. Nevertheless, further studies are required, in order to provide substantial insight to the exact mechanisms of CYP1A1 regulation in extrahepatic tissues.

\section{CYPIAI polymorphisms}

Several mutations in CYP1A1 have been found, corresponding to 15 different allelic variants http:// www.imm.ki.se/CYPalleles. The first of these polymorphisms, CYP1A1* involves a thymidine to cytosine substitution at position 3801 of the $3^{\prime}$ non-coding region downstream of the polyadenylation site [96]. Should the nucleotide change be found to be in the same position at the 3 ' non-coding region only, it is denoted CYP1A1*2B [97]. The second most commonly encountered CYP1A1 polymorphism involves an Adenine to Guanine base transition at position $2455 \mathrm{~A} \rightarrow \mathrm{G}$ of codon 462 at exon 7 , and is also known as CYP1A1*2B or Ile $462 \mathrm{Val}$ due to the amino acid change [97]. If the amino acid is located in the haem-binding region, the corresponding variant is referred to as CYP1A1*2C [98].

Conventional theory regarding the effect of polymorphisms on CYP1A1 suggests that the variants affect the function of the enzyme by altering the level of gene expression or the mRNA stability, although the results in the literature appear to be contradictory [98]. For example, the Ile462Val polymorphism was found to confer increased levels of induced or basal CYP1A1 mRNA as the number of Val variants increased in one study, whereas in purified Escherichia Coli, no difference in the metabolism of benzo[a]pyrene between the Ile and Val variants was noted $[99,100]$. Similarly, a high activity or lack of correlation has been suggested with the 3801TC and Ile462Val polymorphisms regarding the activity of mutant enzymes in lymphocytes [101-104].

Generally, evidence regarding the association of genetic polymorphisms of CYP1A1 with cancer occurrence is conflicting, as some studies have concluded that there is increased susceptibility to cancer in the presence of polymorphic variants, whereas others have reported no relationship between the two $[105,106]$. Although a large body of experimental results points towards a positive association of CYP1A1 genetic polymorphisms and cancer occurrence, further investigation is required for such findings to be extrapolated successfully to human populations.

\section{Intracellular localization of CYPIA I}

Cytochrome P450s are generally located in the endoplasmic reticulum and require the coenzyme NADPH reductase which catalyzes the two electron reduction of molecular $\mathrm{O}_{2}$ to $\mathrm{H}_{2} \mathrm{O}$ for their enzymatic activity. Early investigations showed that in addition to the ER localization, CYP1A1 is present in the mitochondria of liver tissue from rats pretreated with $\beta$-napthoflavone, a CYP1 inducer $[107,108]$. Subsequent studies revealed that CYP1A1 is present in both endoplasmic reticulum and mitochondrial inner membrane, depending on the tissue, animal age and inducer pretreatment. The enzyme is targeted to the mitochondria by proteolysis of cryptic MTtargeting signals, which remove a certain number of amino acids from the $\mathrm{NH}_{2}$ terminus, thus producing two alternative truncated isoforms of mitochondrial CYP1A1 (mt1A1). Mouse mt-Cyp1a1 shows distinct substrate specificity from the ER-associated form and metabolizes erythromycin as well as a number of psychotropic drugs, probably due to the presence of ferredoxin-1-reductase (FDX1) as a coenzyme, in place of the NADPH reductase found in the microsomal CYP1A1 [109]. A previous study supports the notion that it is the microsomal (mcCyp1a1) rather than the mitochondrial form of the enzyme (mtp-Cyp1a1) which contributes to $\mathrm{B}[a] \mathrm{P}$ detoxication, by experiments in three knock-in C57B4/6J mice lines [110]. Cyp1a1(-/-) and Cyp1a1(mtp/mtp) mice showed striking toxicity following 18 days of daily oral $\mathrm{B}[\mathrm{a}] \mathrm{P}$ treatment, compared to wild-type and Cyp1a1 (mc/ $\mathrm{mc}$ ) mice, which were completely protected [110].

\section{CYPIAI contribution to cancer prevention}

The most significant line of evidence which contradicts the previously proposed carcinogen-activating role of CYP1A1, comes from Nebert and the generation of Cyp1a1 (-/-) knockout mice. C57BL/6J mice lacking the Cyp1a1 gene died within 30 days of $125 \mathrm{mg} / \mathrm{kg} /$ day oral $\mathrm{B}[a] \mathrm{P}$ treatment, whereas Cyp1a1 $(+/+)$ mice survived with no overt signs of toxicity [111]. In addition, the clearance rate of $\mathrm{B}[a] \mathrm{P}$ in the Cyp1a1 (-/-) strain was 4 times slower as compared to Cyp1a1 (+/+) mice, while further pharmacokinetic experiments using TCDD and $\mathrm{B}[a] \mathrm{P}$ suggested that clearance was almost exclusively dependent on inducible CYP1A1 and no other TCDD-B $[a] \mathrm{P}$-induciblemetabolizing phase I enzyme [111]. B $[a] \mathrm{P}$ treatment had toxic effects in the immune system of Cyp1a1 (-/-) mice, while chemical depression of the bone marrow was noted at a dose as low as $1.25 \mathrm{mg} / \mathrm{kg} /$ day [111]. The data showed for the first time that this enzyme is more important in detoxication of $\mathrm{B}[a] \mathrm{P}$ in the liver and intestine, rather than metabolic activation to its ultimate carcinogenic conversion products. From this initial observation the same group published a series of studies where Cyp1a1/1b1 (-/ -) double knockout and Cyp1a1/1a2/1b1 (-/-) triple knockout mouse lines were generated from straightforward genetic crosses of Cyp1a1 (-/-), Cyp1b1 (-/-) and 
Cyp1a2 (-/-) knockout mice and tested for their ability to metabolize $\mathrm{B}[a] \mathrm{P}$. Compared with Cyp $(+/+)$ wild-type mice, the Cyp1a1/1b1 (-/-) mice showed $\sim 75$ fold higher amounts of blood $\mathrm{B}[a] \mathrm{P}$ after 5 days of feeding, demonstrating that the total body burden of $\mathrm{B}[a] \mathrm{P}$ is independent of target organ damage [112]. The phenotype of this transgenic line revealed decreased spleen and thymus weights and increased liver weights [112]. Despite this discrepancy Cyp1a1/1b1 (-/-) and Cyp1b1 (-/-) mice displayed no significant difference in cellularity of the bone marrow following $\mathrm{B}[a] \mathrm{P}$ treatment as opposed to Cyp1a1 $(-/-)$ mice. B[a]P-DNA adduct patterns in Cyp1a1/1b1 (-/ -) doubleknockout mice were proportionate to the relative degree of immunotoxicity and followed the order Cyp1a1 (-/-) > >> Cyp1a1/1b1 (-/-) > Cyp (+/+) [112]. Thus although CYP1A1 contributes to detoxication, CYP1B1 expression in spleen and marrow is responsible for the metabolic activation of $\mathrm{B}[a] \mathrm{P}$, causing immune damage in mice which lack the Cyp1b1 gene [112]. The same "rescued" response following oral $\mathrm{B}[a] \mathrm{P}$ treatment was observed in the triple knockout Cyp1a1/1a2/1b1 (-/) mouse line, i.e. the absence of CYP1B1 in immune tissues is sufficient to avoid substantial bone marrow depression [113]. The phenotypic abnormalities of the triple knockout mouse line, which included a greater risk of embryolethality before gestational day 11, hermaphroditism and formation of cystic ovaries, were attributed to alterations in the production catabolism and/or formation of eicosanoids, bioactive mediators derived from arachidonic acid via $\omega-6$ fatty acid synthesis and from eicosapentanoic acid via $\omega-3$ fatty acids, which are involved in inflammation, innate immunity, angiogenesis and various other developmental processes [113]. Given that human and mouse CYP1A1 and CYP1A2 orthologs differ in the rates of metabolism of xenobiotics, Nebert and colleagues proceeded in the generation of a "humanized" hCYP1A1_CYP1A2_Cyp1a1/1a2 (-/-) mouse line. The successful insertion of both human CYP1A in place of the mouse Cyp1a genes returns the phenotype of the Cyp1a1/1a2 (-/-) double knockout line back to approximately that of the wild type, whereas the human CYP1A1 enzyme partially rescues the animal from oral $\mathrm{B}[a] \mathrm{P}-$ induced immunosuppresion [114]. Although the hCYP1A1_CYP1A2_Cyp1a1/1a2 (-/-) mouse line offers unique opportunities for direct human CYP1A1 in vivo carcinogen metabolism studies caution should be taken as to whether results can successfully be extrapolated to human populations. For example, it is possible that the mouse relies more on the small intestine than the liver for $\mathrm{B}[a] \mathrm{P}$ metabolism, whereas the opposite may be true for humans. Such organ differences regarding the metabolism of xenobiotics between the two species should be taken into account and further experiments are required to provide a full understanding of the use of this transgenic model in environmental toxicology and cancer pharmacology.
As mentioned earlier CYP1A1 enzyme expression is linked with important physiological and cell growth regulatory processes, through the involvement of AhR with multiple pathways other than the xenobiotic activating pathway. Recent experiments performed in lung tissue from mice which were AhR-null, suggest that AhR and CYP1A1 are subjected to an autoregulatory feedback loop, thus supporting the presence of an as yet unidentified endogenous ligand. Since the transient transfection of CV1 cells with a CYP1A1 and an AhR expression vector led to a markedly reduced DRE-driven luciferase reporter activity, the authors of this study proposed that CYP1A1 in turn metabolizes the putative endogenous ligand, resulting in its inactivation and consequently in the attenuation of the AhR pathway [115]. As well as unraveling the precise contribution of this enigmatic orphan receptor in normal cellular metabolism, such evidence can add to the significance of excessive activation of AhR by xenobiotics and the identification of new molecular targets for therapeutic drug development [115].

Regarding the pharmacological aspects of CYP1A1 xenobiotic-mediated metabolism accumulated evidence has corroborated the recent knockout mice findings, suggesting a cancer-protecting role of the enzyme by paradoxical activation of small synthetic molecules, as well as natural products present in the diet, to more antiproliferative agents. The synthetic compound Phortress or 2-(4Amino-3-methylphenyl) benzothiazole is a CYP1A1-activated prodrug with potent in vivo activity in breast tumor xenografts [116]. Of note is that the natural AhR ligand indirubin and Phortress possess a very similar structure based on a benzimidazole ring. Nevertheless, this compound was not initially designed for the purpose of CYP1A1 induction. Initial studies suggested it had promising antitumour effects; however, its exact mechanism of action was elucidated in subsequent studies. Phortress, which entered early Phase I clinical trials in 2004, induces CYP1A1 in breast cancer sensitive cell lines, such as MCF7, T-47D and IGROV ( IC $\left._{50}<10 \mathrm{nM}\right)$ and is further metabolized by CYP1A1 to reactive electrophillic species which results in DNA adduct formation [116-118]. This induction involves the binding of AhR to ARNT and translocation of the complex to the nucleus, as observed in the case of benzo[a]pyrene [119]. Another chemotherapeutic agent in this category, aminoflavone, also acts by the induction of CYP1A1 and its subsequent activation. Aminoflavone is active in MCF7 cell lines $\left(\mathrm{IC}_{50}=0.1 \mathrm{nM}\right)$ and MCF7 xenografts [120]. Again, AhR is required for CYP1A1 induction, rendering this compound 4,500-fold less active in MCF7 AhR-null mutant cells. Induced CYP1A1, in turn, converts aminoflavone to metabolites that form DNA protein crosslinks and cause DNA doublestrand breaks, thereby inhibiting DNA synthesis in the S phase [121]. The molecular pathway of CYP1A1-mediated aminoflavone activation is shown in Figure 4A. 
A small number of naturally occurring phytochemicals, which belong to the flavonoid subclass, have recently been identified as CYP1A1 substrates. The flavonoid eupatorin found in medicinal plants in South East Asia and South America, was recently shown to be converted to the structurally similar flavone cirsiliol, by an aromatic demethylation reaction catalysed by the enzymes CYP1A1 and CYP1B1 [122]. Eupatorin strongly inhibits the in vitro proliferation of MDA-MB-468 human breast cancer cells that express CYP1A1, but it is inactive in normal breast MCF-10A cells, devoid of any CYP1A1 activity [122]. The isoflavone daidzein, a component of soy beans, is a substrate for CYP1A1 as demonstrated by in vitro enzyme and cell-based assays [123]. Aromatic hydroxylation of daidzein at the 3' position enhances the antiproliferative activity of the compound in MCF-7 cells [123]. Similarly, the flavone diosmetin, present in olive leaves, is activated to the flavone luteolin, mainly by CYP1A1. CYP1A1-mediated metabolism of diosmetin in MDA-MB-468 and TCDD-induced MCF-7 cells increases its biological activity $[124,125]$. A recent study has reported that CYP1A1 has the highest rate of metabolism, compared to the hepatic CYPs 1A2, 3A4, 2C9 and 2D6, of fully methylated anticancer flavonoids such as tangeretin, a high constituent of orange peel [126]. The flavonols galangin and kaempferide have also been reported to be substrates of

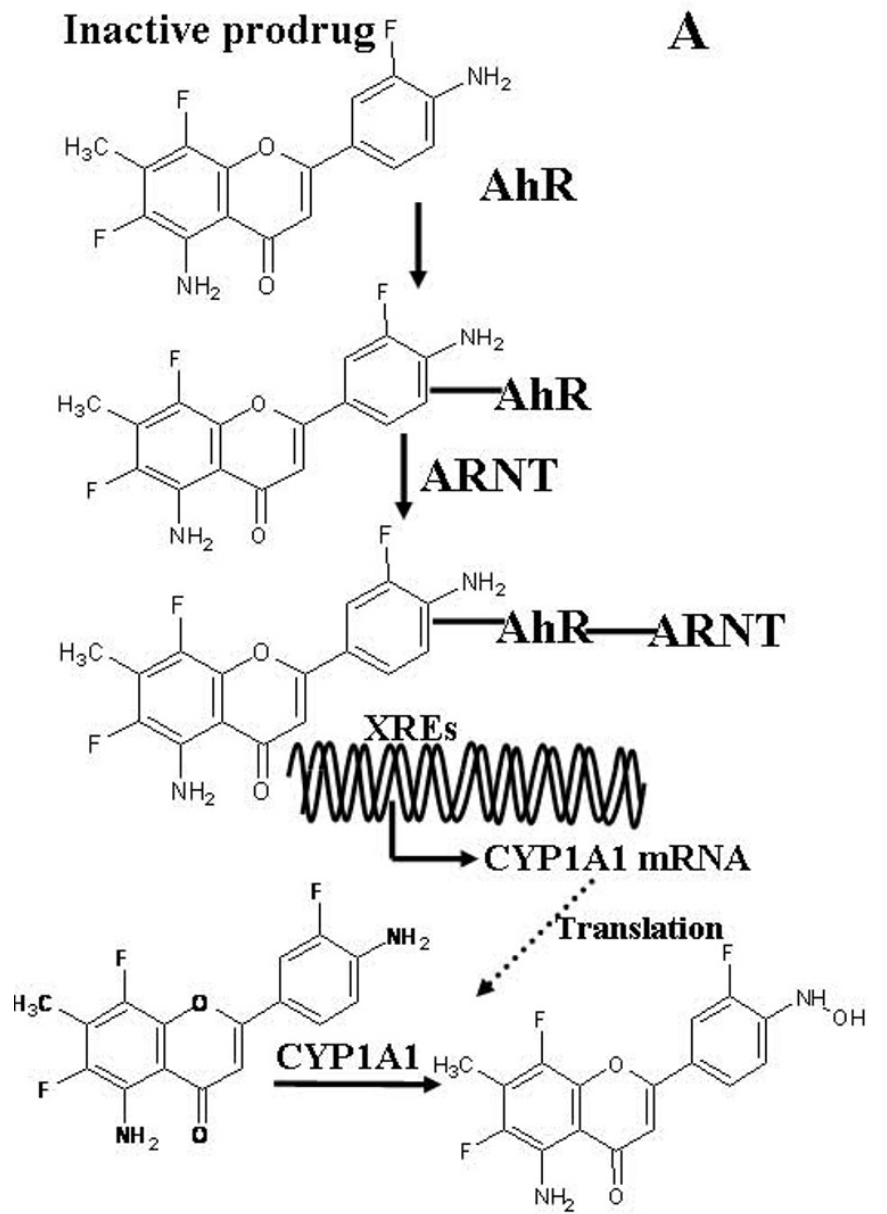

Active drug

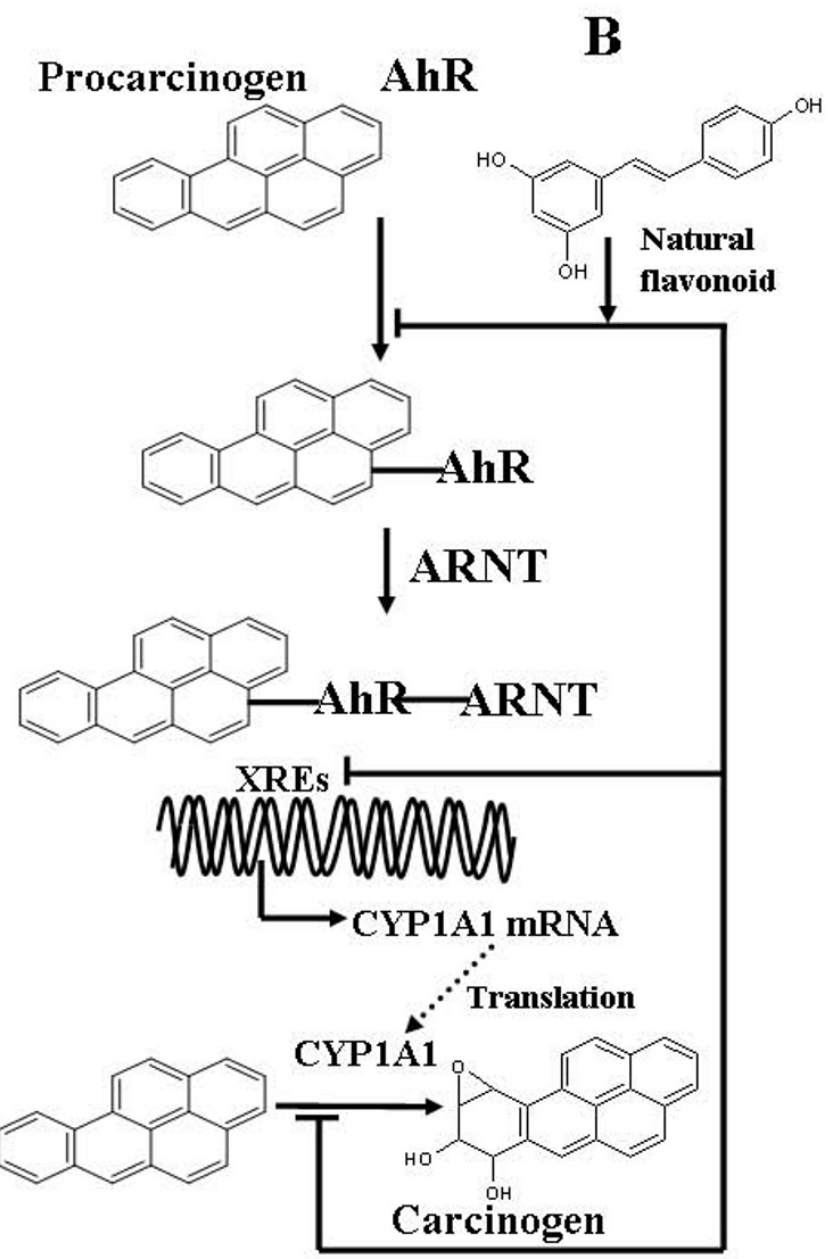

Figure 4

The two different models for the contribution of CYPIAI to chemoprevention. (A) Molecular mechanism of aminoflavone AhR-induced CYPIAI activation. It must be stressed that this mechanism of action is also likely to apply for certain dietary natural products, such as the flavonoid diosmetin, which induces CYPIAI expression and is a substrate of the same enzyme [129, I24, I 25]. (B) Chemopreventative action of natural products, such as the stilbene resveratrol, is based on the inhibition of benzo[a]pyrene binding to AhR, the binding of the AhR-ARNT-benzo[a]pyrene complex to xenobiotic response elements (XREs), and the inhibition of the formation of CYPIAI-mediated carcinogenic reactive intermediates, notably benzo[a]pyrene-7,8-diol-9, I0-epoxide. 
CYP1A1 [127]. Kaempferide is demethylated, while galangin is hydroxylated at position 4' to produce kaempferol another anticancer flavonoid found in black and green tea [128]. Of note is that the CYP1A1-catalyzed metabolism of dietary anticancer flavonoids produces compounds that also possess strong cancer preventative activity.

Certain flavonoids are capable of inducing CYP1A1 activity via the AhR in cancer cell line models [129-131]. The hypothesis that has been established by such findings follows the so-called blocking type of chemopreventative agent. Dietary constituents suppress cancer progression by inhibiting the CYP1A1-catalyzed metabolic activation and the CYP1A1 enzyme induction of carcinogens. The second occurs either by the blockage of AhR binding to the inducer or by the prevention of AhR-ARNT binding to XREs (Figure 4B) [132]. Although most of the compounds examined possess inhibitory activity against CYP1A1, the model does not adequately explain why CYP1A1 is induced and further inhibited. As the AhR-mediated induction of CYP1A1 is noted for a large amount of phytochemicals present in the diet, it can be assumed that the subsequent metabolism of these compounds is the end stage of this process, as has been noted for the procarcinogen benzo[a]pyrene [133]. More importantly, in in vitro or in vivo models where cell lines with a malignant phenotype are used, the inhibition of CYP1A1 ought not to alter the tumorigenic state of the cells, since they have already lost the ability to control their growth. In this sense, the action of dietary flavonoids and phytochemicals as CYP1A1 inhibitors is subject to further consideration. The induction of CYP1A1 in cancer cells by dietary compounds and their subsequent metabolism to more active agents is an alternative model that can explain the cancer preventative properties of these compounds in pharmacologically relevant concentrations [134]. In addition, many compounds that appear as CYP1A1 competitive inhibitors may well be CYP1A1 substrates.

\section{Conclusion}

P450s are believed to have existed since the beginning of life over 3.5 billion years ago, but the P450s responsible for foreign compound metabolism appear to have arisen about 400 to 500 million years ago. It is believed that these enzymes were needed to metabolise and detoxify chemicals found in plants [135]. In the plant-animal "warfare" hypothesis, plants produce toxins to kill predators and animals evolve P450s to detoxify these toxins. As this process continues over millions of years new catalytic activities of P450s will develop. However, in the field of chemical carcinogenesis it is difficult to establish a clear relationship in which both the P450s and other foreign compound metabolizing enzymes would evolve for a beneficial purpose.
Although the majority of the studies have focused on the carcinogenic action of CYP1A1, it is recently becoming clear that this enzyme plays important roles in detoxication and chemoprevention, thus opposing the initially established concept, regarding its function in tumor progression. Moreover, extensive work on the molecular events governing the transcriptional activation of the CYP1A1 gene through the aryl hydrocarbon receptor has revealed the interplay of AhR with various cell signaling pathways, important in normal cell growth, homeostasis and development. The cross-talk of AhR with different signal transduction pathways is apparent. However, the precise mechanisms by which AhR ligands elicit toxic responses that may contribute to carcinogenesis still remain unclear. It was previously noted that this may be partially due to the majority of the studies coming from cancer-derived cell lines that have impaired cell cycle regulation and hence do not possess the full detoxication battery [34]. Studies in non-transformed cells or extrahepatic tissues have been proposed as better models of choice [34]. Utilization of these systems can unravel the exact mechanisms which regulate the expression of CYP1A1 in extrahepatic tissues, and offer insight into the contribution of the latter in cancer progression or prevention.

\section{List of abbreviations}

CYP1A1: cytochrome P450 1A1; AhR: aryl hydrocarbon receptor; ARNT: aryl hydrocarbon nuclear translocator; PAH: polycyclic aromatic hydrocarbon; HIF-1: hypoxia inducible factor 1; bHLH: basic helix-loop-helix; PAS: perARNT-sim; HREs: hypoxia response elements; DREs: dioxin response elements, XREs: xenobiotic response elements; HSP90: heat-shock protein; XAP2: hepatitis B virus $\mathrm{X}$-associated protein; AhRR: aryl hydrocarbon receptor repressor; SOCS-2: suppressor of cytokine signaling 2; VDAC2: voltage-dependent anion channel-selective protein 2; Cyp1a1(mc/mc): transgenic line carrying endoplasmic reticulum-targeted CYP1A1 protein; Cyp1a1(mtp/mtp): transgenic line carrying mitochondrial-targeted CYP1A1 via proteolysis; Cyp1a1(-/-): null mice lacking the Cyp1a1 gene; Cyp1a1/1b1(-/-): double knockout transgenic line lacking both Cyp1a1 and Cyp1b1 gene; Cyp1a1/1a2/1b1(-/-): triple knockout transgenic line lacking all three Cyp1 genes; hCYP1A1_CYP1A2_Cyp1a1/1a2(-/-): humanised transgenic line containing CYP1A genes in place of the mouse orthologs; EROD: 7-ethoxyresorufin-O-deethylase; ER: Estrogen receptor; GR: Glucocorticoid receptor; VEGF: Vascular endothelial growth factor; PDGF: Plateletderived growth factor; Rb: Retinoblastoma; SRC-1: steroid receptor co-activator; NcoA2: nuclear co-activator 2; MAPK: mitogen activated protein kinase; ERK: extracellular signal-regulated kinase; JNK: jun N-terminal kinase; 
MEK: mitogen-activated extracellular signal regulated kinase.

\section{Competing interests}

The authors declare that they have no competing interests.

\section{Authors' contributions}

VPA participated in literature research and preparation of the first draft of the manuscript. AMT contributed substantially to the conception and design of the second draft of the manuscript. DAS made critical revisions for important intellectual content and has given approval of the final version to be published. All authors have read and approved the manuscript.

\section{References}

I. Wei Q, Gu J, Cheng L, Bondy ML, Jiang H, Hong WK, Spitz MR: Benzo [a]pyrene diol epoxide-induced chromosomal aberrations and risk of lung cancer. Cancer Res 1996, 56:3975-3979.

2. Buterin T, Hess MT, Luneva N, Geacintov NE, Amin S, Kroth H, Seidel A, Naegeli H: Unrepaired fjord region polycyclic aromatic hydrocarbon-DNA adducts in ras codon 61 mutational hot spots. Cancer Res 2000, 60:1849-1856.

3. Hankinson O: The aryl hydrocarbon receptor complex. Ann Rev Pharmacol Toxicol 1995, 35:307-340.

4. Conney $\mathrm{AH}$ : Induction of microsomal enzymes by foreign chemicals and carcinogenesis by polycyclic aromatic hydrocarbons: GHA. Clowes memorial lecture. Cancer Res 1982, 4:4875-49|7.

5. Guengerich FP, Shimada T: Oxidation of toxic and carcinogenic chemicals by human cytochrome $\mathbf{P 4 5 0}$ enzymes. Chem Res Toxicol I99I, 4:39I-407.

6. Shimada T, Fujii-Kuriyama Y: Metabolic activation of polycyclic aromatic hydrocarbons to carcinogens by cytochromes $\mathrm{P} 450$ IAI and IBI. Cancer Sci 2004, 95: I-6.

7. Tang M-shong, Vulimiri SV, Viaje A, Chen JX, Bilolikar DS, Morris RJ, Harvey RG, Slaga TJ, DiGiovanni J: Both ( \pm ) syn- and ( \pm ) anti-7, $12-$ dimethylbenz [a] anthracene-3,4-diol-1,2-epoxides initiate tumors in mouse skin that possess-CAA- to CTA- mutations at codon 6I of c-H-ras. Cancer Res 2000, 60:5688-5695.

8. Shimada T, Oda Y, Gillam EMJ, Guengerich FP, Inoue K: Metabolic activation of polycyclic aromatic hydrocarbons and other procarcinogens by cytochromes P450 IAI and P450 IBI allelic variants and other human cytochromes P450 in Salmonella typhimurium NM2009. Drug Metab Dispos 200I, 29: II76-II82.

9. Shimada T, Inoue K, Suzuki $Y$, Kawai T, Azuma E, Nakajima T, Shindo M, Kurose K, Sugie A, Yamagishi Y, Fujii-Kuriyama Y, Hashimoto M: Arylhydrocarbon receptor-dependent induction of liver and lung cytochromes P450 IAI, IA2 and IB I by polycyclic aromatic hydrocarbons and polychlorinated biphenyls in genetically engineered C57BL/6] mice. Carcinogenesis 2002, 23:1199-1207.

10. Shimizu $Y$, Nakatsura $Y$, Ichinose M, Takahashi $Y$, Kume H, Mimura J, Fujii-Kuriyama $Y$, Ishikawa $T$ : Benzo[a]pyrene carcinogenicity is lost in mice lacking the aryl hydrocarbon receptor. Proc Natl Acad Sci USA 2000, 97:779-782.

II. Shimada T, Hayes CL, Yamazaki H, Amin S, Hecht SS, Guengerich FP, Sutter TR: Activation of chemically diverse procarcinogens by human cytochrome P450 IBI. Cancer Res 1996, 56:2979-2984.

12. Luch A, Schober W, Soballa VJ, Raub G, Greim H, Jacob J, Doehner J, Seidel A: Metabolic activation of dibenzo[ $a$, I]pyrene by human cytochrome P450 IA I and I I expressed in V79 Chinese hamster cells. Chem Res Toxicol 1999, I 2:353-364.

13. Ma X, Idle JR, Malfatti MA, Krausz KW, Nebert DW, Chen C, Felton JS, Waxman DJ, Gonzalez FJ: Mouse lung CYPIAI catalyzes the metabolic activation of 2-amino-I-methyl-6-phenylimidazo[4,5-b]pyridine (PhIP). Carcinogenesis 2007, 28:732-737.

14. Cheung C, Ma X, Krausz KW, Kimura S, Feigenbaum L, Dalton TP, Nebert DW, Idle JR, Gonzalez FJ: Differential metabolism of 2-
amino-I-methyl-6-phenylimidazo[4,5-b]pyridine (PhIP) in mice humanized for CYPIAI and CYPIA2. Chem Res Toxicol 2005, I8: | 47|- | 478.

15. Friesen MD, Kaderlik K, Lin D, Garren L, Bartsch H, Lang NP, Kadlubar FF: Analysis of DNA adducts of 2-amino-I-methyl-6-phenylimidazo[4,5-b]pyridine in rat and human tissues by alkaline hydrolysis and gas chromatography/electron capture mass spectrometry: validation by comparison with $32 \mathrm{P}$ postlabeling. Chem Res Toxicol 1994, 7:733-739.

16. Snyderwine EG, Yu M, Schut HA, Knight-Jones L, Kimura S: Effect of CYPIA2 deficiency on heterocyclic amino DNA adduct levels in mice. Food Chem Toxicol 2002, 40:1529-1533.

17. Cheung C, Ma X, Krausz KW, Kimura S, Feigenbaum L, Dalton TP, Nebert DW, Idle Fujita K, Kamataki T: Predicting the mutagenicity of tobacco-related $\mathrm{N}$-nitrosamines in humans using I I strains of Salmonella typhimurium YG7 108, each coexpressing a form of human cytochrome P450 along with NADPHcytochrome P450 reductase. Environ Mol Mutagenesis 200I, 38:339-346.

18. Fujita K, Kamataki T: Role of human cytochrome P450 (CYP) in the metabolic activation of $\mathrm{N}$-alkylnitrosamines: application of genetically engineered Salmonella typhimurium YG7108 expressing each form of CYP together with human NADPHcytochrome $\mathbf{P 4 5 0}$ reductase. Mutation Res 200I, 483:35-4I.

19. Puga $\mathrm{A}, \mathrm{Ma} \mathrm{C}$, Marlowe JL: The aryl hydrocarbon receptor cross-talks with multiple signal transduction pathways. Biochem Pharmacol 2009, 77:7 I3-722.

20. Hankinson O: Role of coactivators in transcriptional activation by the aryl hydrocarbon receptor. Arch Biochem Biophys 2005, 433:379-386.

21. Mimura J, Fujii-Kuriyama Y: Functional role of AhR in the expression of toxic effects by TCDD. Biochim Biophys Acta 2003, 1619:263-268.

22. Fujii-Kuriyama Y, Mimura J: Molecular mechanisms of AhR functions in the regulation of cytochrome $\mathbf{P 4 5 0}$ genes. Biochem Biophys Res Commun 2005, 338:31 I-3 I7.

23. Wang S, Ge K, Roeder RG, Hankinson O: Role of mediator in transcriptional activation by the aryl hydrocarbon receptor. J Biol Chem 2004, 279: 13593-13600.

24. Wei YD, Tepperman K, Huang MY, Sartor MA, Puga A: Chromium inhibits transcription from polycyclic aromatic hydrocarboninducible promoters by blocking the release of histone deacetylase and preventing the binding of p300 to chromatin. J Biol Chem 2004, 279:4I I0-4II 9.

25. Kung T, Murphy KA, White LA: The aryl hydrocarbon receptor (AhR) pathway as a regulatory pathway for cell adhesion and matrix metabolism. Biochem Pharmacol 2009, 77:536-546.

26. Chan WK, Yao G, Gu YZ, Bradfield CA: Cross-talk between the aryl hydrocarbon receptor and hypoxia inducible factor signaling pathways. J Biol Chem 1999, 274:121 I5-12123.

27. Carrier F, Owens RA, Nebert DW, Puga A: Dioxin-dependent activation of murine Cypla-I gene transcription requires protein kinase C-dependent phosphorylation. Mol Cell Biol 1992, I2:1856-1863.

28. Ikegwuonu FI, Christou M, Jefcoate CR: Regulation of cytochrome P450IBI (CYPIBI) in mouse embryo fibroblast (C3H I OTI/2) cells by protein kinase C (PKC). Biochem Pharmacol 1999, 57:619-630.

29. Ikuta T, Kobayashi Y, Kawajiri K: Phosphorylation of nuclear localization signal inhibits the ligand-dependent nuclear import of aryl hydrocarbon receptor. Biochem Biophys Res Commun 2004, 317:545-550.

30. Ikuta T, Kobayashi $Y$, Kawajiri K: Cell density regulates intracelIular localization of aryl hydrocarbon receptor. J Biol Chem 2004, 279: 19209-19216.

31. Diry M, Tomkiewicz C, Koehle C, Coumoul X, Bock KW, Barouki R, Transy C: Activation of the dioxin/aryl hydrocarbon receptor (AhR) modulates cell plasticity through a JNK-dependent mechanism. Oncogene 2006, 25:5570-5574.

32. Tan $Z$, Huang $M$, Puga $A, X i a Y$ : A critical role for MAP kinases in the control of Ah receptor complex activity. Toxicol Sci 2004, 82:80-87.

33. Tan Z, Huang M, Puga A, Xia Y: Activation of mitogen-activated protein kinases (MAPKs) by aromatic hydrocarbons: role in the regulation of aryl hydrocarbon receptor (AHR) function. Biochem Pharmacol 2002, 64:77I-780. 
34. Henklová P, Vrzal R, Ulrichová J, Dvoøák Z: Role of mitogen-activated protein kinases in aryl hydrocarbon receptor signaling. Chem-Biol Interact 2008, I 72:93-104.

35. Chen S, Operama T, Bonzo J, Nguyen N, Tukey RH: ERK kinase inhibition stabilizes the aryl hydrocarbon receptor: implications for transcriptional activation and protein degradation. J Biol Chem 2005, 280:4350-4359.

36. Ma Q, Whitlock JPJ: The aromatic hydrocarbon receptor modulates the Hepa $|c| c 7$ cell cycle and differentiated state independently of dioxin. Mol Cell Biol 1996, I6:2I44-2I50.

37. Elizondo G, Fernandez-Salguero P, Sheikh MS, Kim GY, Fornace AJ, Lee KS, Gonzalez Fl: Altered cell cycle control at the $\mathbf{G ( 2 ) / M}$ phases in aryl hydrocarbon receptor-null embryo fibroblast. Mol Pharmacol 2000, 57:1056-1063.

38. Gierthy JF, Crane D: Reversible inhibition of in vitro epithelial cell proliferation by $2,3,7,8$-tetrachlorodibenzo-p-dioxin. Toxicol Appl Pharmacol 1984, 74:91-98.

39. Huska DR, Greenlee WF: 2,3,7,8-Tetrachlorodibenzo-p-dioxin inhibits DNA synthesis in rat primary hepatocytes. Mutat Res 1995, 333:89-99.

40. Bauman JW, Goldsworthy TL, Dunn CS, Fox TR: Inhibitory effects of 2,3,7,8-tetrachlorodibenzo-p-dioxin on rat hepatocyte proliferation induced by $2 / 3$ partial hepatectomy. Cell Prolif 1995, 28:437-45।.

41. Wang W, Smith IR, Safe S: Aryl hydrocarbon receptor-mediated antiestrogenicity in MCF-7 cells: Modulation of hormoneinduced cell cycle enzymes. Arch Biochem Biophys 1998, 356:239-248.

42. Hestermann EV, Stegeman JJ, Hahn ME: Relationships among the cell cycle, cell proliferation, and aryl hydrocarbon receptor expression in PLHC-I cells. Aquat Toxicol 2002, 58:201-2I3.

43. Barnes-Ellerbe S, Knudsen KE, Puga A: 2,3,7,8-Tetrachlorodibenzo-p-dioxin blocks androgen-dependent cell proliferation of LNCaP cells through modulation of pRB phosphorylation. Mol Pharmacol 2004, 66:502-5 II.

44. Levine-Fridman A, Chen L, Elferink CJ: Cytochrome P450IAI promotes $\mathrm{GI}$ phase cell cycle progression by controlling aryl hydrocarbon receptor activity. Mol Pharmacol 2004, 65:46I-469.

45. Marlowe JL, Puga A: Aryl hydrocarbon receptor, cell cycle regulation, toxicity and tumorigenesis. J Cell Biochem 2005, 96: $1174-84$

46. Ge N-L, Elferink C]: A direct interaction between the aryl hydrocarbon receptor and retinoblastoma protein. J Biol Chem 1998, 273:22708-22713.

47. Chan HM, Smith L, La Thangue NB: Role of LXCXE motifdependent interactions in the activity of the retinoblastoma protein. Oncogene 2001, 20:6152-6163.

48. Puga A, Barnes S], Dalton TP, Chang C, Knudsen ES, Maier MA: Aromatic hydrocarbon receptor interaction with the retinoblastoma protein potentiates repression of E2F-dependent transcription and cell cycle arrest. I Biol Chem 2000, 275:2943-2950.

49. Chang X, Fan Y, Karyala S, Schwemberger S, Tomlinson CR, Sartor $M A$, Puga A: Ligand-independent regulation of transforming growth factor $\beta I$ expression and cell cycle progression by the aryl hydrocarbon receptor. Mol Cell Biol 2007, 27:6127-6I39.

50. Yang X, Solomon S, Fraser LR, Trombino AF, Liu D, Sonenshein GE, Hestermann EV, Sherr DH: Constitutive regulation of CYP I B I by the aryl hydrocarbon receptor (AhR) in pre-malignant and malignant mammary tissue. J Cell Biochem 2008, 104:402-417.

5I. Monostory K, Kohalmy K, Prough RA, Kobori L, Vereczkey L: The effect of synthetic glucocorticoid, dexamethasone on CYPIAI inducibility in adult rat and human hepatocytes. FEBS Lett 2005, 579:229-235.

52. Bielefeld KA, Lee C, Riddick DS: Regulation of aryl hydrocarbon receptor expression and function by glucocorticoids in mouse hepatoma cells. Drug Metab Dispos 2008, 36:543-55I

53. Prough RA, Linder MW, Pinaire JA, Xiao GH, Falkner KC: Hormonal regulation of hepatic enzymes involved in foreign compound metabolism. Faseb J 1996, I0:1369-1377.

54. Lai KP, Wong MH, Wong CK: Modulation of AhR-mediated CYPIAI MRNA and EROD activities by I 7beta-estradiol and dexamethasone in TCDD-induced H4I IE cells. Toxicol SCi 2004, 78:4I-49.
55. Celander M, Hahn ME, Steceman J]: Cytochromes P450 (CYP) in the Poeciliopsis Iucida hepatocellular carcinoma cell line (PLHC-I): dose- and time- dependent glucocorticoid potentiation of CYPIA induction without induction of CYP3A. Arch Biochem Biophys 1996, 329: I I3-I22.

56. Dvoøak Z, Vrzal R, Pávek P, Ulrichová J: An evidence for regulatory cross-talk between aryl hydrocarbon receptor and glucocorticoid receptor in HepG2 cells. Physiol Res 2008, 57:427-435

57. Vrzal R, Stejskalova L, Monostory K, Maurel P, Bachleda P, Pavek P, Dvorak Z: Dexamethasone controls aryl hydrocarbon receptor (AhR)-mediated CYPIAI and CYPIA2 expression and activity in primary cultures of human hepatocytes. Chem Biol Interact 2009, I 79:288-296.

58. Pearce ST, Liu H, Radhakrishnan I, Abdelrahim M, Safe S, Jordan VC: Interaction of the aryl hydrocarbon receptor ligand 6methyl- I,3,8-thrichlorodibenzofuran with oestrogen receptor alpha. Cancer Res 2004, 64:2889-2897.

59. Safe S, Wormke M: Inhibitory aryl hydrocarbon receptorestrogen receptor alpha cross-talk and mechanisms of action. Chem Res Toxicol 2003, 16:807-816.

60. Matthews J, Wihlén B, Thomsen J, Gustafsson J: Aryl hydrocarbon receptor-mediated transcription: ligand-dependent recruitment of estrogen receptor $\alpha$ to 2,3,7,8-tetrachlorodibenzop-dioxin-responsive promoters. Mol Cell Biol 2005, 25:5317-5328.

61. Sarkar S, Jana NR, Yonemoto J, Tohyama C, Sone H: Estrogen enhances induction of cytochrome P-450 I AI by 2,3,7,8-tetrachlorodibenzo- $p$-dioxin in liver of female Long-Evans rats. Int J Oncol 2000, 16:141-147.

62. Han W, Pentecost BT, Pietropaolo RL, Fasco MJ, Spivack SD: Estrogen receptor $\alpha$ increases basal and cigarette smoke extractinduced expression of CYP IA I and CYP I B I, but not GSTP I in normal human bronchial epithelial cells. Mol Carcinogenesis 2005, 44:202-2II.

63. Ohtake F, Takeyama K, Matsumoto H, Kitagawa H, Yamamoto $Y$, Nohara K, Tohyama C, Krust A, Mimura J, Chambon P, Yanagisawa J, Fujii-Kuriyama $Y$, Kato S: Modulation of oestrogen receptor signaling by association with the activated dioxin receptor. Nature 2003, 423:545-550.

64. Schmidt JV, Bradfield CA: AH receptor signaling pathways. Ann Rev Cell Dev Biol 1996, I 2:55-89.

65. Blancher C, Harris AL: The molecular basis of the hypoxia response pathway: Tumor hypoxia as a therapy target. Cancer and Metastasis Rev 1998, 17:187-194.

66. Wood SM, Gleadle JM, Pugh CW, Hankinson O, Ratcliffe PJ: The role of the aryl hydrocarbon receptor nuclear translocator (ARNT) in hypoxic induction of gene expression-Studies in ARNT deficient cells. J Biol Chem 1996, 271:151 I7-I5I23.

67. Chan WK, Yao G, Gu YZ, Bradfield CA: Cross-talk between the aryl hydrocarbon receptor and hypoxia inducible factor signaling pathways. J Biol Chem 1999, 274: I2I I5- I 2123.

68. Zhang N, Walker MK: Crosstalk between the aryl hydrocarbon receptor and hypoxia on the constitutive expression of cytochrome P450 I AI mRNA. Cardiovasc Toxicol 2007, 7:282-290.

69. Frericks M, Burgoon LD, Zacharewski TR, Esser C: Promoter analysis of TCDD-inducible genes in a thymic epithelial cell line indicates the potential for cell-specific transcription factor crosstalk in the AhR response. Toxicol Appl Pharmacol 2008, 232:268-279.

70. Bhakta KY, Jiang W, Couroucli XI, Fazili IS, Muthiah K, Moorthy B: Regulation of cytochrome P450 I A I expression by hyperoxia in human lung cell lines. Toxicol Appl Pharmacol 2008, 233:169-178.

7I. Bernauer U, Heinrich-Hirsch B, Tönnies M, Peter-Matthias W Gundert-Remy U: Characterisation of the xenobiotic-metabolizing cytochrome P450 expression pattern in human lung tissue by immunochemical and activity determination. Toxicol Lett 2006, I 64:278-288.

72. Wei C, Caccavale RJ, Weyand EH, Chen S, Iba MM: Induction of CYPIAI and CYPIA2 expressions by prototypic and atypical inducers in the human lung. Cancer Lett 2002, I 78:25-36.

73. Wei C, Caccavale RJ, Kehce JJ, Thomas PE, Iba MM: CYPIA2 is expressed along with CYPIAI in the human lung. Cancer Lett 2001, I71:113-120. 
74. Chang TJ, Chang H, Chen P, Lin S, Lin P: Requirement of aryl hydrocarbon receptor overexpression for CYPIB I up-regulation and cell growth in human lung adenocarcinomas. Clin Cancer Res 2007, 13:38-45.

75. Anttila S, Hakkola J, Tuominen P, Elovaara E, Husgafvel-Pusiainen K, Karjalainen A, Hirvonen A, Nurminen T: Methylation of cytochrome P450IAl promoter in the lung is associated with tobacco smoking. Cancer Res 2003, 63:8623-8628.

76. Oyama T, Sugio K, Uramoto H, Iwata T, Onitsuka T, Isse T, Nozoe T, Kagawa N, Yasumoto K, Kawamoto T: Increased cytochrome $\mathbf{P 4 5 0}$ and aryl hydrocarbon receptor in bronchial epithelium of heavy smokers with non-small cell lung carcinoma carries a poor prognosis. Front Biosci 2007, I 2:4497-4503.

77. Oyama T, Sugio K, Uramoto H, Kawamoto T, Kagawa N, Nadaf S, Carbone D, Yasumoto K: Cytochrome P450 expression (CYP) in non-small cell lung cancer. Front 2007, I 2:2299-2308.

78. Murray GI, Taylor MC, McFadyen MC, McKay JA, Greenlee WF, Burke MD, Melvin WT: Tumor specific expression of Cytochrome P450 CYPIB I. Cancer Res 1997, 57:3026-303I.

79. McKay JA, Melvin WT, Ah-See AK, Ewen SW, Greenlee WF, Marcus $\mathrm{CB}$, Burke MD, Murray Gl: Expression of cytochrome P450 CYPIB I in breast cancer. FEBS Lett 1995, 374:270-272.

80. McKay JA, Murray GI, Ah-See AK, Greenlee WF, Marcus CB, Burke MD, Melvin WT: Differential expression of CYPIAI and CYPIBI in human breast cancer. Biochem Soc Trans 1996, 24:327S

8I. Goth-Goldstein R, Stampfer MR, Erdmann CA, Russell M: Interindividual variation in CYPIAI expression in breast tissue and the role of genetic polymorphism. Carcinogenesis 2000, 2l:2l 19-2। 22

82. Liehr JG, Ricci MJ: 4-Hydroxylation of estrogens as marker of human mammary tumors. Proc Nat Acad Sci USA 1996, 93:3294-3296

83. Murray GI, Shaw D, Weaver RJ, McKay JA, Ewen SW, Melvin WT, Burke MD: Cytochrome P450 expression in oesophageal cancer. Gut 1994, 35:599-603.

84. Murray GI, Taylor VE, McKay JA, Weaver RJ, Ewen SW, Melvin WT, Burke MD: Expression of xenobiotic metabolizing enzymes in tumors of the urinary bladder. Int J Exp Pathol I995, 76:27|-276.

85. Syme MR, Paxton JW, Keelan JA: Drug transfer and metabolism by the human placenta. Clin Pharmacokinet 2004, 43:487-5I4.

86. Myllynen $P$, Pasanen $M$, Vähäkangas $K$ : The fate and effects of xenobiotics in human placenta. Expert Opin Drug Metab Toxicol 2007, 3:331-346.

87. Pavek $P$, Dvorak Z: Xenobiotic-induced transcriptional regulation of xenobiotic metabolizing enzymes of the cytochrome P450 superfamily in human extrahepatic tissues. Curr Drug Metab 2008, 9: | 29-|43.

88. Avery ML, Meek CE, Audus KL: The presence of inducible cytochrome P450 types IAI and IA2 in the BeWo cell line. Placenta 2003, 24:45-52.

89. Kolwankar D, Glover DD, Ware JA, Tracy TS: Expression and function of $A B C B I$ and $A B C G 2$ in human placental tissue. Drug Metab Dispos 2005, 33:524-529.

90. Hakkola J, Pasanen M, Pelkonen O, Hukkanen J, Evisalmi S, Anttila S, Rane A, Mäntylä M, Purkunen R, Saarikoski S, Tooming M, Raunio H: Expression of CYPIBI in human adult and fetal tissues and differential inducibility of CYPIB I and CYPIAI by Ah receptor ligands in human placenta and cultured cells. Carcinogenesis 1997, 18:391-397.

91. Walle T: Absorption and metabolism of flavonoids. Free Radic Biol Med 2004, 36:829-837.

92. Paine MF, Hart HL, Ludington SS, Haining RL, Rettie AE, Zeldin DC: The human intestinal cytochrome $\mathbf{P 4 5 0}$ "pie". Drug Metab Dispos 2006, 34:880-886

93. McDonnell WM, Scheiman JM, Traber PG: Induction of cytochrome P450IA genes (CYPIA) by omeprazole in the human alimentary tract. Gastroenterology 1992, I03:1509-1516.

94. Eskin SG, Turner NA, Mclntire LV: Endothelial cell cytochrome P450 IAI and IB I: up-regulation by shear stress. Endothelium 2004, I I: I- 10

95. Conway DE, Sakurai Y, Weiss D, Vega JD, Taylor WR, Jo H, Eskin SG, Marcus CB, Mclntire LV: Expression of CYPIAI and CYPIB I in human endothelial cells: regulation by fluid shear stress. Cardiovasc Res 2009, 81:669-677.
96. Bale AE, Nebert DW, McBride OW: Subchromosomal localization of the dioxin-inducible P I 450 locus (CYPI) and description of two RFLPs detected within a 3' PI450 cDNA probe. Cytogenet Cell Genet 1987, 46:574-575.

97. Hayashi S, Watanabe J, Nakachi K, Kawajiri K: Genetic linkage of lung cancer-associated Mspl polymorphisms with amino acid replacement in the heme binding region of the human cytochrome P450 IAI gene. J Biochem I 99I, I I 0:407-4I I.

98. Tabor HK, Risch NJ, Myers RM: Opinion: candidate-gene approaches for studying complex genetic traits: practical considerations. Nat Rev Genet 2002, 3:391-397.

99. Crofts F, Taioli E, Trachman J, Cosma GN, Currie D, Toniolo P, Garte S): Functional significance of different human CYPIAI genotypes. Carcinogenesis 1994, I 5:296 I-2963

100. Zhang ZY, Fasco MJ, Huang L, Guengerich FP, Kaminsky LS: Characterization of purified human recombinant cytochrome P450IAI-Ile462 and -Val462: assessment of a role for the rare allele in carcinogenesis. Cancer Res 1996, 87:।8-24.

I0I. Cosma G, Crofts F, Taioli E, Toniolo P, Carte S: Relationship between genotype and function of the human CYPIAI gene. J Toxicol Environ Health 1993, 40:309-316.

102. Kiyohara C, Hirohata T, Inutsuka S: The relationship between aryl hydrocarbon hydroxylase and polymorphisms of the CYPIAI gene. Jpn J Cancer Res 1996, 87:।8-24.

103. Daly AK, Fairbrother KS, Smart J: Recent advances in understanding the molecular basis of polymorphisms in genes encoding cytochrome P450 enzymes. Toxicol Lett 1998, I02103:143-147.

104. Smart J, Daly AK: Variation in induced CYPIA I levels: relationship to CYPIAI, Ah receptor and GSTMI polymorphisms. Pharmacogenetics 2000, 10: I 1-24.

105. Nakachi K, Imai K, Hayashi S, Kawajiri K: Polymorphisms of the CYPIAI and glutathione S-transferase genes associated with susceptibility to lung cancer in relation to cigarette dose in a Japanese population. Cancer Res 1993, 53:2994-2999.

106. Kelsey KT, Wiencke JK, Spitz MR: A race-specific genetic polymorphism in the CYPIAI gene is not associated with lung cancer in African Americans. Carcinogenesis 1994, I 5: I I 2 I- I I 24.

107. Niranjan BG, Avadhani NG, DiGiovanni J: Formation of benzo[a]pyrene metabolites and DNA adducts catalyzed by a rat liver mitochondrial monooxygenase system. Biochem Biophys Res Commun 1985, I3 I:935-942.

108. Raza H, Avadhani NG: Hepatic mitochondrial cytochrome P. 450 system. Purification and characterization of two distinct forms of mitochondrial cytochrome P-450 from b-naphthoflavone-induced rat liver. J Biol Chem 1988, 263:9533-954 I.

109. Anandatheerthavarada HK, Vijayasarathy C, Bhagwat SV, Biswas G, Mullick J, Avadhani NG: Physiological role of the $\mathbf{N}$-terminal processed P450 I AI targeted to mitochondria in erythromycin metabolism and reversal of erythromycin-mediated inhibition of mitochondrial protein synthesis. J Biol Chem 1999, 274:66 I7-6625

I 10. Dong H, Dalton TP, Miller ML, Chen Y, Uno S, Shi Z, Shertzer HG, Bansal S, Avadhani NG, Nebert DW: Knock-in mouse lines expressing either mitochondrial or microsomal CYPIAI: Differing responses to dietary benzo[a]pyrene as proof of principle. Mol Pharmacol 2009, 75:555-567.

III. Uno S, Dalton TP, Derkenne S, Curran CP, Miller ML, Shertzer HG, Nebert DW: Oral exposure to benzo[a]pyrene in the mouse: Detoxication by inducible cytochrome $\mathbf{P 4 5 0}$ is more important than metabolic activation. Mol Pharmacol 2004, 65:1225-1237.

1 12. Uno S, Dalton TP, Dragin N, Curran CP, Derkenne S, Miller ML, Shertzer HG, Gonzalez FJ, Nebert DW: Oral benzo[a]pyrene in Cyp I knockout mouse lines: CYPIAI important in detoxication, CYPIBI metabolism required for immune damage independent of total-body burden and clearance rate. Mol Pharmacol 2006, 69: I I03-III4.

I 13. Dragin N, Shi Z, Madan R, Karp CL, Sartor MA, Chen C, Gonzalez FJ, Nebert DW: Phenotype of the CyplaI/Ia2/IbI(-/-) tripleknockout mouse. Mol Pharmacol 2008, 73: I844-I856.

I14. Dragin N, Uno S, Wang B, Dalton TP, Nebert DW: Generation of 'humanized' CYPIAI_IA2_CypIaI/Ia2(-/-) mouse line. Biochem Biophys Res Commun 2007, 359:635-642. 
I I5. Chiaro CR, Patel RD, Marcus CB, Perdew GH: Evidence for an aryl hydrocarbon receptor-mediated cytochrome $P 450$ autoregulatory pathway. Mol Pharmacol 2007, 72:1369-I379.

116. Chua MS, Kashiyama E, Bradshaw TD, Stinson SF, Brantley E, Sausville EA, Stevens MFG: Role of CYPIAI in modulation of antitumor properties of the novel agent 2-(4-amino-3-methylphenyl)benzothiazole (DF 203, NSC 674495) in human breast cancer cells. Cancer Res 2000, 60:5196-5203.

I 17. Brantley E, Trapani V, Alley MC, Hose CD, Bradshaw TD, Stevens MGF, Sausville EA, Stinson SF: Fluorinated 2-(4-amino-3-methylphenyl)benzothiazoles induce CYPIAI expression, become metabolized, and bind to macromolecules in sensitive human cancer cells. Drug Metab Dispos 2004, 32: I392-I40 I.

I 18. Bradshaw TD, Westwell AD: The development of the antitumor benzothiazole prodrug, Phortress as a clinical candidate. Curr Med Chem 2004, I I:I009-102I.

I 19. Trapani V, Patel V, Leong CO, Ciolino HP, Yeh GC, Hose C, Trepel JB, Stevens MF, Sausville EA, Loaiza-Pérez AI: DNA damage and cell cycle arrest induced by 2-(4-amino-3-methylphenyl)-5fluorobenzothiazole (5F 203, NSC 703786) is attenuated in aryl hydrocarbon receptor deficient MCF-7 cells. $\mathrm{Br} J$ Cancer 2003, 88:599-605.

120. Loaiza-Pérez AI, Kenney S, Boswell J, Hollingshead M, Alley MC, Hose C, Ciolino HP, Yeh GC, Trepel JB, Vistica DT, Sausville EA: Aryl hydrocarbon receptor activation of an antitumor aminoflavone: Basis of selective toxicity for MCF-7 breast tumor cells. Mol Cancer Ther 2004, 3:71 5-725.

I2I. Meng LH, Shankavaram U, Chen C, Agama K, Fu HQ, Gonzalez FJ, Weinstein J, Pommier $Y$ : Activation of aminoflavone (NSC $\mathbf{6 8 6 2 8 8 )}$ by a sulfotransferase is required for the antiproliferative effect of the drug and for induction of histone gammaH2AX. Cancer Res 2006, 66:9656-9664.

122. Androutsopoulos V, Arroo RRJ, Hall JF, Surichan S, Potter GA: Antiproliferative and cytostatic effects of the natural product eupatorin due to CYPI mediated metabolism. Breast Cancer Res 2008, 10:R39.

123. Atherton K, Mutch E, Ford D: Metabolism of the soyabean isoflavone daidzein by CYPIA2 and the extra-hepatic CYPs I AI and IB I affects biological activity. Biochem Pharmacol 2006, 72:624-3I.

124. Androutsopoulos V, Wilsher N, Arroo RRJ, Potter GA: Bioactivation of the phytoestrogen diosmetin by CYPI cytochromes P450. Cancer Lett 2009, 274:54-60.

125. Androutsopoulos VP, Mahale S, Arroo RRJ, Potter G: Anticancer effects of the flavonoid diosmetin on cell cycle progression and proliferation of MDA-MB 468 breast cancer cells due to CYPI activation. Oncol Rep 2009, 2 I:1525-1528.

126. Walle UK, Walle T: Cytochrome P450-mediated metabolism of methoxyflavones. Drug Metab Dispos 2007, 35: I 985- I 989.

127. Otake Y, Walle T: Oxidation of the flavonoids galangin and kaempferide by human liver microsomes and CYPIAI, CYPIA2 and CYP2C9. Drug Metab Dispos 2002, 30:103-I 05.

128. Somerset SM, Johannot L: Dietary flavonoids sources in Australian adults. Nutr Cancer 2008, 60:442-449.

129. Ciolino HP, Wang TTY, Yeh GC: Diosmin and diosmetin are agonists of the aryl hydrocarbon receptor that differentially affect cytochrome P450 IAI activity. Cancer Res 1998, 58:2754-2760

130. Ciolino HP, Daschner PJ, Yeh GC: Dietary flavonols quercetin and kaempferol are ligands of the aryl hydrocarbon receptor that affect CYPIAI transcription differentially. Biochem J 1999 , 340:715-722

131. Ciolino HP, Yeh GC: The flavonoid galangin is an inhibitor of CYPIAI activity and an agonist/antagonist of the aryl hydrocarbon receptor. Br J Cancer 1999, 79:1340-1346.

132. Ciolino HP, Yeh GC: Inhibition of aryl hydrocarbon-induced cytochrome P-450 I A I enzyme activity and CYP I A I expression by resveratrol. Mol Pharmacol 1999, 56:760-767.

133. Denison MS, Nagy SR: Activation of the aryl hydrocarbon receptor by structurally diverse exogenous and endogenous chemicals. Ann Rev Pharmacol Toxicol 2003, 43:309-334.

134. Arroo RRJ, Androutsopoulos V, Patel A, Surichan S, Wilsher N, Potter GA: Phytoestrogens as natural prodrugs in cancer prevention: a novel concept. Phytochem Rev 2008:431-443.
135. Gonzalez FJ, Gelboin HV: Role of human cytochromes $\mathbf{P 4 5 0}$ in the metabolic activation of chemical carcinogens and toxins. Drug Metab Rev 1994, 26: 165-183.

\section{Pre-publication history}

The pre-publication history for this paper can be accessed here:

http://www.biomedcentral.com/1471-2407/9/187/pre pub
Publish with Bio Med Central and every scientist can read your work free of charge

"BioMed Central will be the most significant development for disseminating the results of biomedical research in our lifetime. "

Sir Paul Nurse, Cancer Research UK

Your research papers will be:

- available free of charge to the entire biomedical community

- peer reviewed and published immediately upon acceptance

- cited in PubMed and archived on PubMed Central

- yours - you keep the copyright

Submit your manuscript here:

http://www.biomedcentral.com/info/publishing_adv.asp
BioMedcentral 